\title{
The Impact Analysis of Privatization and Shariah Screening on Financial Performance and Shares Return of State Owned Enterprises as the member of Jakarta Islamic Index
}

\author{
Mursid Lubis ${ }^{1}$, Yuzwar Z. Basri ${ }^{1} \&$ Tatik Mariyanti $^{1}$
}

\author{
${ }^{1}$ Trisakti University, Jakarta, Indonesia \\ Correspondence: Mursid Lubis, Trisakti University, Jakarta, Indonesia, E-mail: willy.arafah@ hotmail.com
}

Received: March 12, 2018

Accepted: March 17, 2018

Online Published: March 21, 2018

\begin{abstract}
Privatization is one of the government's programs in restructuring State-Owned Enterprises (SOEs). Other than restructuring SOE, privatization is also source of state budget funds (APBN). By privatizing SOE, government expected healthy corporation that will contribute larger tax payments, dividend payments, and additional paid-in capital. So it is expected that SOEs are always in a healthy condition, high competitive and produce goods quality products and services.In order to invite Islamic foreign investors. Now also available public listed SOEs that is according to Islamic sharia. SOE sharia shares are expected to be an example of implementing business in accordance to sharia, will benefit better financial performance and better share price. Eight SOEs who are members of the Jakarta Islamic Index, those are WSKT, WIKA, PTPP, SMGR, TLKM, PTBA, ANTM and PGAS, will be evaluated in this research regarding their financial performance and stock performance during the period 2000 to 2016.This research is included in descriptive research method that is ex post facto. The researcher evaluated the company's financial performance and stock performance during the 17 -year period, from 2000 to 2016, financial performance measured is profitability performance (NPM, ROA and ROE), solvency (Total Asset Turnover) activity (Debt to Equity Ratio). The measurement of stock performance those are EPS. PER and PBV. Data analysis used in this research is descriptive analysis, trend analysis and Test $t$ test.Based on the results of the study, the variable condition before the regression, NPM, ROA, ROE, DER, DR, DI, S / TA, EPS, PER and PBV variables have scattered residues normally. However, when tested for heteroscedasticity using scatter diagrams these variables such are NPM, ROA, ROE and PER free from heteroscedasticity. But variables such as DER, DR, DI, S/TA, EPS and PBV variables tend to contain heteroscedasticity. NPM variable data, tends to increase every year, as well as ROA, ROE. However, DER, DR, DI, S / TA, EPS, PER and PBV variables tend to be stable from year to year.Through a simultaneous equation method that reflects the existence of circular causation, it gives an idea of all variables being independent and dependent. Variable net profit margin on each SOE member JII, influenced significantly by the variable ROE, DER, DR, PER, PBV. The variable return on asset is influenced by ROE and DER variables significantly. The return on equity variable is significantly influenced by NPM, ROA, DER, PER and PBV variables. Debt To Equity Ratio (DER) variables are influenced significantly variables of NPM, ROA, ROE, DER, PER and PBV. Days Receivable (DR) variables influenced by NPM variables significantly.Days Inventory variables are not affected by any variable. Variable of Asset Turn Over (S / TA) is influenced by one variable only that is EPS. Variable Earning per Share (EPS) influenced significantly by variable DER and S / TA. Price Earning Ratio (PER) variables are significantly influenced by NPM, ROE, DER, and PBV. Price to Book Value (PBV) variables are significantly influenced by NPM, ROE, DER and PER variables.
\end{abstract}

Keywords: BUMN, JII, Financial Performance, Net Profit Margin, Return on Asset, Return on Equity, Total Asset Turnover, Debt to Equity Ratio, Earning per Share, Price Earning Ratio, Price to Book Value.

\section{Introduction}

This journal will analyze the financial condition, price and share return of some State Owned Enterprises (SOEs) that have gone public and included into the group of Jakarta Islamic Index. Some SOEs have been facing 
financial health problems. This condition is confirmed by the statement of the Minister of Finance of the Republic of Indonesia, Sri Mulyani speaking in front of the House of Representatives in Jakarta representing the Minister of SOEs, (August $24^{\text {th }} 2016$ ) that someSOEs condition up to now has not improved. The problem that often faced by SOEs is inefficient, bad quality products, less competitive and others. According to BPK representative Achsanul Qosasi, 54 percent of the loss was due to missinvestment or redundant investment, released in public discussion "Optimization of BUMN Dividend" (Kompas Online, Friday 23/1/2015).

Based on the Ministry of SOEs (2016) information, some SOEs currently problems is illiquid, those SOEs become very dependent on third party funds, from national and foreign banks, it could be seen from the data, that Debt to Equity Ratio (DER) or Short-term Debt to capital ratio from year 2010 to 2015 averaged 329.95\%. The result of large short-term debt, SOEs bear highinterest expense. Then create shortage of funds, old machineries due to no source fund to renew production facilities, low income or negative income, and bad quality products or services. The condition of over leverage or high debt burden becomes one of the criteria, whether listed SOEs or companies that have gone public are categorized according to sharia principles or not.

Investors of stock exchange will consider whether to buy the shares, keep long-term or sell the shares based on the financial performance of SOEs (Sinta Wardani and Rachma Fitriati, 2010 quoting Dermawan, 1999). Three financial ratios that can be used to predict stock returns for investors (Hanani, 2011 quotes Samsul, 2006). The ratios are Earning Per Share (EPS), Return on Equity (ROE) and Debt to Equity Ratio (DER). Earning per Share (EPS) can be used as an analytical tool to determine the level of profitability of a company (Hanani, 2011).

Meanwhile, Return on Equity (ROE) is one of the profitability ratios used by investors to know the capability of the company in using the funds to operate the companyin generating profit by utilizing its assets (Ang, 1997). Another ratio that can affect the return of a stock is Debt to Equity Ratio (DER). Debt to Equity Ratio (DER) is a solvency ratio that measures company's performance capability in returning long term debt or long-term debt by comparing total debt to total equity (Ang, 1997). In theory, the higher the Return on Assets (ROA), shows that the company is more effective and efficient in utilizing the assets in generating net profit after tax (Rivai and Sagala, 2009).

It is also known that the Return On Equity (ROE) has a positive relationship with the stock price, because generally the greater the Return On Equity (ROE), the greater the stock price.The high level of ROE indicates that the return received by investors will be high, so investors are interested in buying or acquiring the shares. Generally stock investors tend to avoid stocks with high Debt to Equity Ratio (DER), because the high Debt To Equity Ratio (DER) shows the high riskcorporation, and this couldbe explained that the higher theEarning Per Share (EPS), indicates greater profit given to shareholders, so this could raise the shares price. Based on the background of the problem and the phenomenon as described above, it can be concluded as follows:

- In some studies on the effect of SOEs privatization, conclude that there has been an increase in performance and its shares return positively but inconsistently, due to the short time span of research ( 2 to 5 years), besides the companies being research are too much and not homogeneous so it looks inconsistent.

- Most of the SOEs that have been privatized, the financial structures are still depend on the debt that contains usury or riba elements, actually by entering the Islamic Index (shariah screening), the dependence on the debt of usury should be getting smaller.

- In relation to the Minister of Finance's criticism that some SOEs have poor financial performance, this journalwill ivestigated whether SOEs that have been privatized and have been screened by sharia into JII groups still have poor financial performance or otherwise have a positive trend, and how is the impact among financial performance variables.

- SOE is the only company in the world that is governed by the Indonesian government, in order not only to 
pursue profit, but also obliged to help small economic group in the form of SMEs, This makes SOE worthy to be examined more deeply whether after in privatization and screening by sharia, still have a good financial performance. In accordance with the mandate of SOE government established not only pursuing profit. Whether the variable financial performance and stock returns still show a positive or negative. This is important because with the better profitability, then the portion of funds to be used for the weak economic program (PKBL) will be greater.

- Theoretically the more transparent a company to external parties as the consequence of listed as a public company, the better the corporate governance of the company. The better governance will increase the effectiveness and efficiency of the company business, so the company should be increasing in value, but the facts show other results, especially SOEs that have gone public. So it is needed to investigate more deeply, whether non-syariah factors (halal haram products, as well as bank interest) become the cause of the failure in increasingthe corporate value. Is the transparency due to go public, shows improvementtrendfor the SOEs.

- Islamic sharia law has clearly prohibited interest or usury, so if the SOEs still depend on the capital of the usury loan, whether it will cause a decrease in the company value. With the inclusion of SOEs into the Jakarta Islamic Index group, then the amount of interest payable (riba) in the company should be smaller. What is the trend after entering the JII group, when interest loans (riba) are smaller, it will result in increasing profits, decreased cost, increased stock prices and so on.

- Government's privatization other than aims to empower SOEs, is also expected to give contribution to the state in the form of tax payments, dividends, and the value added form privatization proceeds, that will be utilized by the government as state source of budget or debt repayment, which will be used as developmentstimulation. The expectation of the privatization is hopefully SOEs will make greater contribution in the form of tax payments and dividends, this could happpenif SOEsprofits increase and the company becomes more efficient. Regarding the SOEs' privatization, government expects SOEs will be more transparent, as public listed companies, formal supervisory will involves third party such as public accountant, Appraisal Company, etc. SOEs as public listed company will be strictly regulated, and it forces SOEs to be ready facing the global market, and competes directly with the international market. The expectation of privatization is to make SOEs more efficient in managing their assets, so this journal is going to analyze the trend of the SOEs financial performance and shares return after going public and screening sharia, whether the variable trends such as days receivable and days inventory will decrease (efficient) and Total Asset Turn Over increasing (effective).

- Some prior research generally discussed the related aspects of privatization of SOEs regarding the efficiency and transparency of SOEs before and after privatization. This study will focus on the facts of SOEs after the privatization and screening process of shariah and observe the effect on financial performance and share returns and the relationship's impact among financial and shares return variables. So the research will discuss the trends of each variables and stock return and how the influences among each variable are after SOEs gopublic and sharia screening and become the Jakarta Islamic Index group.

\section{Theoretical Basis}

According to Jumingan (2006), Financial Performance is a description of the company's financial condition in a certain period concerning the aspect of fund raising for capital and the use or distribution of capital funds, as measured by capital adequacy indicator, liquidity, profitability of stock return and stock price.

While Fahmi (2012), financial performance is a picture of the achievement of the company's success that can be interpreted as a result that has been achieved on various activities that have been done. More details of financial 
performance are an analysis conducted to see how far a company has been carrying out business activities by using the rules of financial implementation properly and correctly.

Profitability Ratios and Rentability Ratios show the company's ability to generate profits at the level of sales, assets and share capital.Profitability ratio measures how big the company's ability to generate profits. According to Gitman (2003) "Profitability is the relationship between revenues and cost generated by using the firm's assetboth current and fixed-in productive activities". Profitability is the ability of a company to generate profits from the sale of its products (Riyanto, 1997).

Net profit margin is the ratio of the ratio between net incomes after tax with sales (Warsono, 2003). The amount of net profit margin calculation shows how much profit after taxes the company earns for a certain level of sales.

$$
\text { Net Profit Margin }=\frac{\text { Net Profit After Tax }}{\text { Net Sales }}
$$

ROA (Return on Assets) is the ratio between net retained earnings after tax with total assets of the company as a whole. ROA also describes the extent to which the return of all assets owned by the company.

According Syahyunan (2004), ROA shows the ability of companies to generate profits from the assets used. The amount of the calculation of return on assets shows how much the ability of the company to generate profits available to ordinary shareholders with all assets owned.

According to Tandelilin (2003), ROA illustrates the extent to which the ability of assets owned by companies to generate profits, ROA ratio obtained by dividing earnings before interest and taxes by the amount of company assets.

Munawir (2002), Return On Assets (ROA) reflects how much the company has gained on the financial resources invested in the company ".

Gibson (2001), Return On assets measures the firm's ability to utilize it's assets to create profits by comparing profit with the assets that generate the profits. Gibson explained that the ratio of ROA is a ratio that measures the ability of companies to take advantage of assets owned by companies to generate revenue by comparing revenue with assets used by companies to generate revenue.

This ratio is used to measure the ability of the capital invested in the overall assets to generate profit for all investors. The calculation results of this ratio shows the effectiveness of management in generating profits related to the availability of corporate assets. ROA value is getting closer to 1 , it means the better profitability of the company because every existing asset can generate profit.

$$
\text { ROA (Return on Asset })=\frac{\text { Net Income }}{\text { Average Total Asset }}
$$

ROE (Return on Equity) is a ratio that indicates a company's ability to generate net income by using its own capital and generating net income available to owners or investors. ROE is very dependent on the size of the company, for example for small companies certainly has a relatively small capital, so the resulting ROE is also small and vice versa for large companies.

ROE (Return on Equity) compares net income after tax with equity invested by company shareholders (Van Horne and Wachowicz, 2005). This ratio shows the power to generate return on investment based on shareholder value books, and is often used in comparing two or more companies for good investment opportunities and cost-effective management.

According to Tandelilin (2002), ROE (Return on Equity) reflects how much the company has earned on funds 
that have been invested by shareholders (either directly or with retained earnings).

Bighram, Enrhardt (2005), ROE (Return on Equity) measures the power of firms to generate profits on book value investments of shareholders.

According to Gibson (2001), Return On Equity measures the return to the common stockholders of the residual owner ". Return on equity consisting of ordinary shares is a measure of return on equity to ordinary shareholders.

$$
R O E\left(\text { Return on Equity) }=\frac{\text { Net Income }}{\text { Average Equity }}\right.
$$

ROE calculation results close to 1 indicate the more effective and efficient use of corporate equity to generate income, and vice versa if the ROE approaching 0 means the company is not able to manage capital efficiently available to generate income. Solvency ratio shows the company's ability to fulfill its long-term obligations. Leverage relates to the use of fixed costs to generate revenues and profits of a company that involves the financing of assets with credit funds from creditors and preferred stockholders who have a fixed rate of return or reward so that it is a liability for the company, the higher the proportion of debt relative to the higher the equity the risks owned companies and affect the ability of companies to share profits with shareholders. Leverage sources can come from long-term debt such as bonds and short-term liabilities of preferred stock (Rahardjo, 2005). This ratio includes:

Total Debt to Total Equity compares Total Liabilities with Total Capital to show the level of corporate financial leverage which is the lower the ratio the better.

Activity ratio or efficiency ratio include:

Average Receivable Age (Days Receivable)

Shows how long the conversion of accounts receivable into cash.This ratio divides accounts receivable with total credit sales multiplied by 365 days which is less days of receivables then the faster it means the better. According to Munawir (2004), the position of the receivables and the estimated time of collection can be assessed by calculating the turn over receivable ie by dividing the total net credit sales with average receivables. According to Warren (2005), accounts receivable turnover is used to measure how often a trade receivable turns into cash within a year.

$$
\text { Perputaran Piutang }=\frac{\text { Penjualan Kredit }}{\text { Piutang Rata }- \text { Rata }}
$$

\section{Average Inventory Age (Days Inventory)}

This ratio shows how long the conversion of inventory to finished goods for one year by dividing the average inventory amount to cost of goods sold multiplied by 365 , the smaller the better. Turn over inventory is the ratio between the total cost of goods sold and the average value owned by the company. This turn over shows how many times the merchandise inventory is replaced within a year (sold and replaced), Munawir (2004).This ratio shows the efficient use of company-owned assets in generating sales by dividing sales by total assets, the greater the better.

Understanding Performance - According to Anwar King (2009), performance is defined as: The results of work in quality and quantity achieved by the management in carrying out its duties in accordance with the responsibilities given to him. Ratios that indicate important company information are disclosed on a per-share basis or view the development of the company's relative value to the book value of the firm.

\section{Total Asset Turnover}

This ratio shows the efficient use of company-owned assets in generating sales by dividing sales by total assets, 
the greater the better.

Understanding Performance - According to Anwar Prabu (2009), performance is defined as: Results of work in quality and quantity achieved by management in performing their duties in accordance with the responsibilities given to him.

Earning Per Shares (EPS)

It is the portion of corporate profits allocated to each existing share that reflects the profitability of the company. EPS is the most important component in calculating stock value. The most commonly used measuring tool is earning per Share (EPS). The figures show from EPS is often published about the performance of companies that sell their shares to the public (go public), because investors and prospective investors hold that the EPS contains information important to predict the amount of dividends per share in the future and the rate of stock return in the future, and EPS are also relevant to assess the effectiveness of management and dividend-sharing policies. According to Tandelilin (2001), a company's EPS information shows the amount of net profit the company is ready to share for all shareholders of the company.

$$
\text { EPS }=\frac{\text { Net Income }}{\text { Outstanding Income }}
$$

Price / Revenue Ratio (Price Earning Ratio) is a commonly used ratio to measure the market price (market price) of each common share with earnings per share. This measure involves an amount that is not directly controlled by the company's ordinary stock market price. The price / earnings ratio reflects investors' valuation of future earnings. (Simamora, 2000).

$$
\text { Price Earning Ratio }=\frac{\text { Harga Saham per Lembar }}{\text { Earning per Lembar Saham }}
$$

The ratio of the market price to the book value (Price to Book Value) is the market share price per share with the book value per share. This ratio compares the market value of investment in the firm with its cost.

A value smaller than 1 means that the company fails to create value for its shareholders. (Rahardjo, 2009). According Rahardjo (2009) Price to Book Value can be calculated by:

$$
P B V=\frac{\text { Harga per Lembar Saham }}{\text { Nilai Buku per Lembar Saham }}
$$

The capital market is a market in which there are various long-term securities (tradable) securities, in the form of debt (bonds) and private equity (shares) issued by the government and private companies (Husnan, 1998).

Savas (1987) defines privatization as an act of reducing the role of the Government or enhancing the role of the private sector especially in activities involving ownership of assets. Pranoto (2011) cites Peacok (1930), defines privatization as a process of transferring industrial ownership from government to the private sector. In his dissertation Pranoto (2011) quotes Dunleavy (1980) interpret privatization as a permanent removal of the production activities of goods and services by state enterprises to the private sector.

According to Abravanel (2006) research also quoted by Pranoto (2011), the benefits received by the Government from the privatization of SOEs are not just the proceeds from the sale of shares in the SOE (IPO Proceed) but also include the interest of local and foreign investors to enter the industry. SOEs efficiency will create cheaper products and services price and the quality of goods / services is better, the opportunity of SOEs to be regional / global champion because of a more competitive business environment, thereby finally increasing shareholder value. In accordance to Law No. 19 of 2003 on State-Owned Enterprises, the notion of privatization is the sales 
of the shares of companies, either partially or wholly, to others in order to improve the performance and value of the enterprise, enlarges the benefits to the state and society, or expands the ownership of shares by the public. Based on this definition, the task of the Ministry of State-Owned Enterprises is: Encouraging SOEs to improve the performance and added value of the company to be superior in the industry as well

SOEs privatization programs in many countries have proven to improve the efficiency of SOEs and encourage economic growth, especially in the sectors of infrastructure, education and health.Increasing public participation in share ownership shareholders.

Some scholars argue especially contemporary fuqaha punish it as a mubah act / may. Among those who punish the mubah are: Yusuf Qardawy, Muhammad Shaltut, Abdurrahman Isa, Dr. Muhammad Abdul Ghafar al-Sharif, Dr. Muhammad Yusuf Musa, Muhammad Rawas Qal'ahji, Umar ibn Abdul Aziz Matrak, and so on, Hamda (2011).

The scope of business activities of issuers that are contrary to the principles of Islamic sharia law are:

a. Gambling and gambling-related businesses or games are prohibited.

b. The business of conventional financial institution containing ribawi element including banking and conventional insurance.

c. Enterprises that produce distribute and trade food and beverages that are classified as haram.

d. Enterprises that produce distribute and provide goods or services that are destructive to morals and harmful.

The main principles of TRS that can be explored (not limited to) are as follows:

- Simultaneous equations of causality (circular causation) on a particular variable. The issue is the definition and explanation that each variable to another variable has a reciprocal relationship (causality), then builds a reciprocal interrelation called circular causation. These variables will form the function of the equation, then the formation of the function of the equation is also named as a simultaneous equation, and all variables in the simultaneous equation are endogenous variables;

- Participatory among agents. In an Islamic perspective defined in several issues as complementary, cooperative and participative, so it does not adopt assumption such as marginal substitution, competition and optimization or maximization. The mathematical calculation method refers to the simulation and iteration than the assumption such as optimization and maximization;

- Form the welfare function $\mathrm{W}(\theta)$ which becomes the dependent variable in the main equation function (simultaneous equations), where at the same time all variables are transformed into induced knowledge-variables $(\theta)$. As it is known that the variable $\mathrm{W}(\theta)$ and the induced knowledge-variable $(\theta)$ have numerical (quantity) and non-numerical (quality) values. This unique equation is formed by taking into account in it the question of ethics, morality and social values in accordance with Islamic views. The equation is expressed as "incomplete equation".

The equations in relation to the dissertation research variables are as follows:

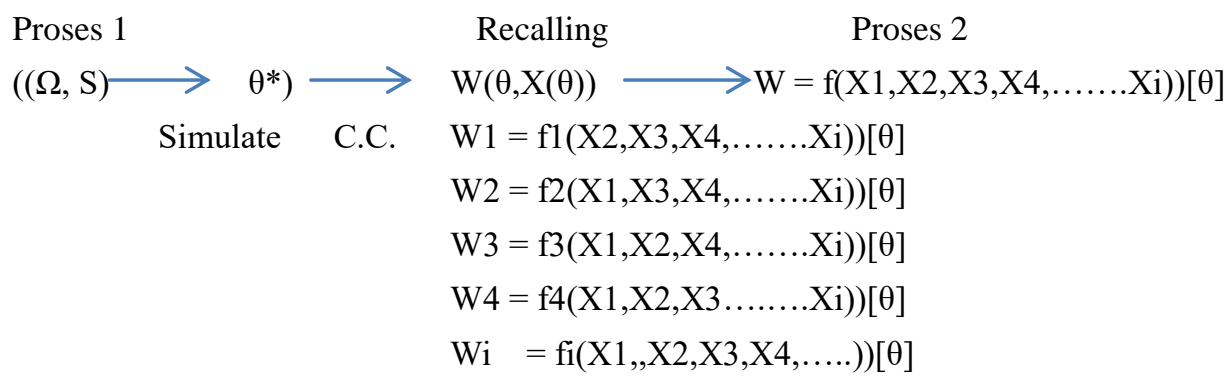

Information:

$\Omega$ : The Science of God 


\section{S: As Sunna}

$\Theta$ : Repaired symbol

W: Wealth (welfare)

F: Function

Xi: variable of financial performance, leverage, return and stock price.

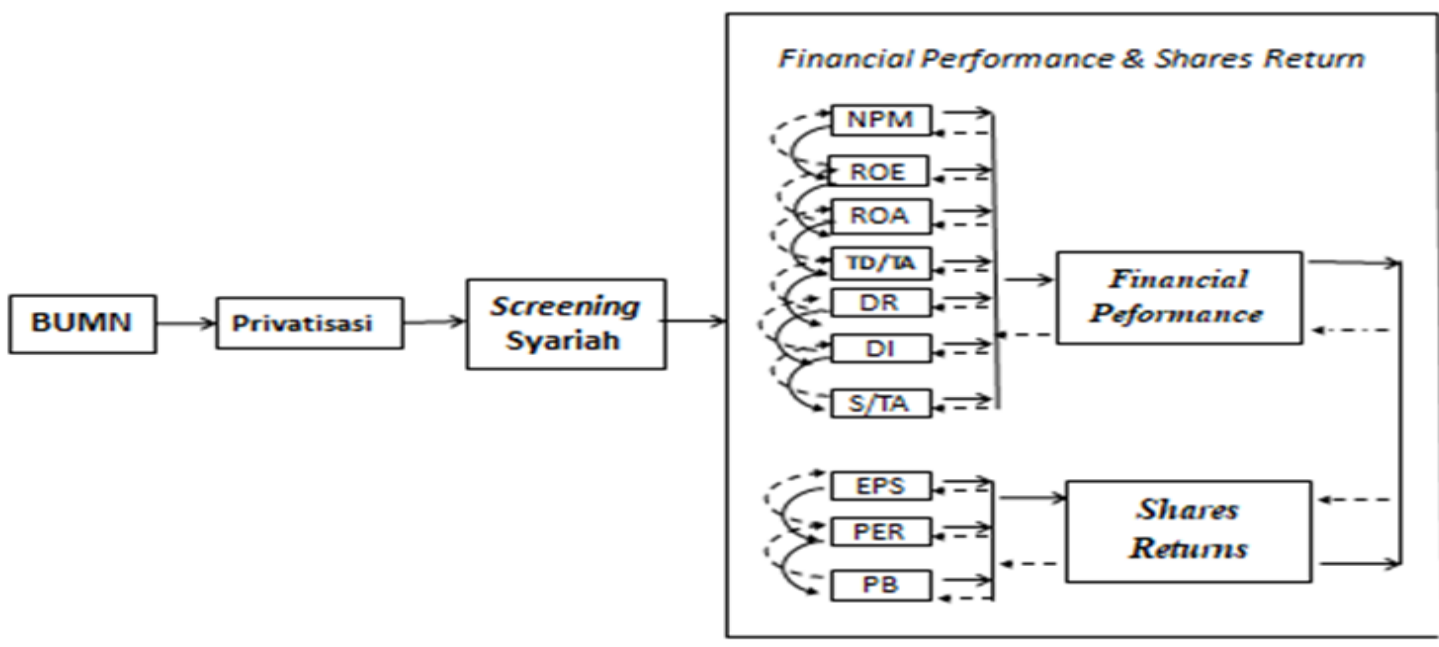

Information:

$\begin{array}{llll}\mathrm{NPM} & =\text { Net Profit Margin } & \text { EPS } & =\text { Earning Per Shares } \\ \text { ROA } & =\text { Return on Asset } & \text { PER } & =\text { Price Earning Ratio } \\ \text { ROE } & =\text { Return on Equity } & P B V & =\text { Price Book Value } \\ \mathrm{TD} / \mathrm{TE} & =\text { Total Debt to Total Equity } & & \\ \mathrm{DR} & =\text { Days Receivable } & & \\ \mathrm{DI} \text { S/TA } & =\text { Days Inventory } & & \\ & =\text { Total Asset Turnover } & \end{array}$

Based on the above explanation of the research can be formulated hypotheses as follows:

Hypothesis 1

Ha: After privatization and screening Shariah financial performance Net Profit Margin BUMN JII member is influenced significantly by Return on Asset (ROA).

H0: after the privatization and screening of Shariah financial performance Net Profit Margin BUMNJII members are not significantly affected by Return on Assets (ROA). In relation to the use of TSR methodology, where all variables simultaneously affect each other, the hypothetical formula is always reversed for each variable, where the dependent variable becomes an independent variable; in this chapter the hypothesis is presented only one instance for each variable, as follows:

Hypothesis 2

Ha: after privatization and screening Shariah financial performance Return on Assets (ROA) SOEs JII members are significantly influenced by Net Profit Margin. 
H0: After privatization and screening Shariah financial performance Return on Assets (ROA) BUMN JII members are not significantly influenced by Net Profit Margin.

\section{Hypothesis 3}

Ha: after privatization and screening Shariah financial performance Return on Equity (ROE) SOE member JII influenced significantly by Net Profit Margin.

H0: After the privatization and screening of Shariah financial performance Return on Equity (ROE)) BUMN JII members are not significantly influenced by Net Profit Margin.

Hypothesis 4

Ha: after privatization and screening Shariah financial performance Total Debt to Total Equity SOE member JII influenced significantly by Net Profit Margin.

H0: after privatization and screening Shariah financial performance Total Debt to Total Equity BUMN JII member is not significantly influenced by Net Profit Margin.

\section{Hypothesis 5}

Ha: after privatization and screening Shariah financial performance Total Debt to Total Equity SOE member JII influenced significantly by Net Profit Margin.

H0: after privatization and screening Shariah financial performance Total Debt to Total Equity BUMN JII member is not significantly influenced by Net Profit Margin.

\section{Hypothesis 6}

Ha: after the privatization and screening of Shariah financial performance of Days Inventory BUMN JII member is significantly influenced by Net Profit Margin.

H0: After the privatization and screening of Shariah financial performance of Days Inventory BUMN JII members are not significantly influenced by Net Profit Margin.

\section{Hypothesis 7}

Ha: after privatization and screening Shariah financial performance Total Assets Turn over state-owned JII members are significantly affected by Net Profit Margin.

H0: after privatization and screening Shariah financial performance Total Assets Turn over state-owned JII members are not significantly influenced by Net Profit Margin.

\section{Hypothesis 8}

Ha: after the privatization and screening Shariah stock performance Earning Per Shares BUMN JII members are significantly affected by Net Profit Margin.

H0: after privatization and screening Shariah stock performance Earning Per Shares BUMN JII members are not significantly influenced by Net Profit Margin.

\section{Hypothesis 9}

Ha: after privatization and screening Shariah performance of Price Earnings Ratio SOE member JII is influenced significantly by Net Profit Margin.

H0: After privatization and screening Shariah stock performance Price Earnings Ratio BUMN JII member is not influenced significantly by Net Profit Margin.

\section{Hypothesis 10}

Ha: after privatization and screening Shariah stock performance Price to Book Value BUMN JII members are significantly influenced by Net Profit Margin.

H0: after privatization and screening Shariah stock performance Price to Book Value BUMN JII members are not significantly influenced by Net Profit Margin.

Analysis method that will be useful in this research is simultaneous equation method. The simultaneous equation 
\begin{tabular}{llll} 
www.cribfb.com/journal/index.php/ijibfr $\quad$ International Journal of Islamic Banking and Finance Research & Vol. 2, No. 1; 2018 \\
\hline
\end{tabular} is the set of equations in which the dependent variable in one or more equations is also an independent variable in some other equation, Sumodiningrat (2007), or can be defined as a model having causality or causal relations between the dependent variable and its independent variable, variables can be expressed as dependent and independent variables in other equations. In TSR view, the concept of simultaneous equations is a reflection of the concept of circular causation.

The simultaneous equations that are affected by theta are as follows:

$$
\begin{aligned}
& \text { 1. } \mathrm{X} 1=\alpha 1.0+\alpha 1.1 \mathrm{X} 2 \Theta+\alpha 1.2 \mathrm{X} 3 \Theta+\alpha 1.3 \mathrm{X} 4 \Theta+\alpha 1.4 \mathrm{X} 5 \Theta+\alpha 1.5 \mathrm{X} 6 \Theta+\alpha 1.6 \mathrm{X} 7 \Theta \\
& +\alpha 1.7 \mathrm{X} 8 \Theta+\alpha 1.8 \mathrm{X} 9 \Theta+\alpha 1.9 \mathrm{X} 10 \quad \Theta \\
& \text { 2. } \mathrm{X} 2=\alpha 2.0+\alpha 2.1 \mathrm{X} 1 \Theta+\alpha 2.2 \mathrm{X} 3 \Theta+\alpha 2.3 \mathrm{X} 4 \mathrm{\Theta}+\alpha 2.4 \mathrm{X} \Theta 5+\alpha 2.5 \mathrm{X} 6 \Theta+\alpha 2.6 \mathrm{X} 7 \mathrm{\Theta} \\
& +\alpha 2.7 \times 8 \Theta+\alpha 2.8 \times 9 \theta+\alpha 2.9 \times 10 \theta \\
& \text { 3. } \mathrm{X} 3=\alpha 3.0+\alpha 3.1 \mathrm{X} 1 \Theta+\alpha 3.2 \mathrm{X} 2 \Theta+\alpha 3.3 \mathrm{X} 4 \Theta+\alpha 3.4 \mathrm{X} 5 \Theta+\alpha 3.5 \mathrm{X} 6 \Theta+\alpha 3.6 \mathrm{X} 7 \Theta \\
& +\alpha 3.7 \times 8 \Theta+\alpha 3.8 \times 9 \theta+\alpha 3.9 \times 10 \Theta \\
& +\alpha 4.7 \mathrm{X} 8 \mathrm{\theta}+\alpha 4.8 \mathrm{X} 9 \mathrm{\theta}+\alpha 4.9 \mathrm{X} 10 \mathrm{\theta} \\
& +\alpha 5.7 \times 8 \Theta+\alpha 5.8 \times 9 \Theta+\alpha 5.9 \times 10 \quad \Theta
\end{aligned}
$$

Information:

1. $\mathrm{X} 1=$ Net Profit Margin (NPM)

2. $\mathrm{X} 2=$ Return on Asset (ROA)

3. $\mathrm{X} 3=$ Return on Equity $(\mathrm{ROE})$

4. X4 = Total Det to Total Equity (TD/TE)

5. $\mathrm{X} 5=$ Days Receivable $(\mathrm{DR})$

6. X6 = Days Inventory (DI)

7. $\mathrm{X} 7=$ Total Asset Turnover $(\mathrm{S} / \mathrm{TA})$

8. $\mathrm{X} 8=$ Earning Per Share (EPS)

9. $\mathrm{X} 9=$ Price Earning Ratio (PER)

10. $\mathrm{X} 10=$ Price Book Value $(\mathrm{PBV})$

11. $\Theta=$ Theta (learning)

The system of simultaneous equations should perform identification tests in advance to detect each equation whether categorized as exactly identifiable, under identified, or over identified.

Once the simultaneous equation model is identified, the next is to do the model estimation.

According to Gujarati (2003), the method of assessment in the method of simultaneous equations is:

1. Indirect Least Square (ILS) 
The least indirect square method is used to estimate an equation that is part of a simultaneous simultaneous system. This method is called the least indirect square. Since structural parameters are estimated indirectly through the estimation of their reduced-form equations, the endogenous variables are only a function of exogenous variables and disturbance variables. Therefore, the ILS technique is only suitable for estimating the exactly identical structural equations that are part of the system of simultaneous equations without restriction on the covariant variant matrix of the disturbance variable.

Gujarati (2003), assumes the use of ILS

1. The structural equation must be exactly identified.

2. The noise variable of the reduced-form equation must satisfy all stochastic assumptions of OLS techniques, since in estimating the reduced-form equations OLS techniques are used. If this assumption is not met then the result of the estimate will be biased.

2. Two Stage Least Squares (2 SLS).

The smallest square with two stages (2SLS), is a single equation method which has correlation between the independent variables, so the OLS technique is applied to each structural equation separately, the simultaneous bias can be eliminated. Theoretically it can be mentioned that the 2SLS method is a development of the ILS method. While the ILS method of interdependence between independent variables and disturbance variables is omitted or bypassed with the application of OLS in its reduced-form equation. The 2SLS method, the independent variables (correlated with the disturbance variables) in substitutions with their own estimates, makes this assumption that these exogenous variables are not accurate, so the approximate structural parameters do not have the required properties.

In the 2SLS method required a considerable amount of obsevarsi data, it is necessary if the model has many exogenous variables. The 2SLS method here has advantages, the 2SLS method still yields its parameter estimates of single value even though the model is over indentified. However, if the model is exactly identified then the ILS and 2SLS procedures will provide the same estimates.

Sumodiningrat (2007), states that the 2SLS method is widely used in practice research is due:

1. The equation is over identified, ILS produces a parameter of double value, while 2SLS produces a single estimate

2. Although 2 SLS is specifically designed to solve over-identified equations, this method can be applied to exactly identifiable equations. In the case of exactly identified results the calculation will be equal to the calculation by the ILS method.

3. Application of the ILS method would be more difficult in estimating the standard error of reduced-form coefficients. While in the application of 2SLS method, there is no such difficulty, this is because the structural keofisien directly assessed from the OLS regression onthe second step.

\section{Instrumental Method Variable}

The background of this method is basically to overcome the relationship between the variable $U$ with free variables by entering a suitable exogenous variable as an instrument, in this method if the correlation between the independent variables and the interference variables can be removed then the procedure OLS produces a reasonable estimate of structural parameters, this procedure is done by the instrument variable method. In this method the structural equations are changed in such a way that the OLS method can be applied to each equation separately. And the transformation can be done by diverting the structural equation with a suitable instrument variable. With such manipulation will eliminate the dependence of independent variables on the interference variables in each equation. A set of equations where the dependent variable in one or more equations is also an independent variable in some other equation. A model that has a causal relationship between the dependent 
variable and the independent variable, so that a variable can be expressed as a dependent variable or independent in other equations.

4. Variables in the simultaneous equation:

a) Endogenous variable: the dependent variable in the simultaneous equation (equal to the number of equations in the simultaneous model).

b) Predetermined variables / predetermined variables: these variables are treated as stochastic variables whose values are already defined or specified.

- Exogenous variables: - Exogenous variables now Xt, Pt

- Exogenous variable of past tense Xt-1, Pt-1

- Endogenous variable of Yt-1, Qt-1

5. Problem Identification in Simultaneous Equations

Identification problems are often found in econometric models of more than one equation, break down as follows:

1. $\mathrm{NPM}=\alpha 0+\alpha 1 R O A \Theta+\alpha 2 R O E \Theta+\alpha 3 \mathrm{TD} / \mathrm{TA} \Theta+\alpha 4 \mathrm{DR} \Theta+\alpha 5 \mathrm{DI} \Theta+\alpha 6 \mathrm{~S} / \mathrm{TA} \Theta+\alpha 7$ EPSO $\alpha 8 P E R \theta+\alpha 9 P B V \theta+\alpha 10 \Theta$

2. $R O A=\alpha 2.0+\alpha 2.1 \mathrm{NPM} \Theta+\alpha 2.2 R O E \Theta+\alpha 2.3 \mathrm{TD} / \mathrm{TA} \Theta+\alpha 2.4 \mathrm{DR} \Theta+\alpha 2.5 \mathrm{DI} \Theta+\alpha 2.6$

$\mathrm{S} / \mathrm{TA} \Theta+\alpha 2.7 E P S \Theta+\alpha 2.8$ PER $\theta+\alpha 2.9 P B V \theta+\alpha 2.10 \Theta$

3. $R O E=\alpha 3.0+\alpha 3.1 \mathrm{NPM} \theta+\alpha 3.2 R O A \theta+\alpha 3.3 \mathrm{TD} / \mathrm{TA} \Theta+\alpha 3.4 D R \theta+\alpha 3.5 \mathrm{DI} \theta+\alpha 3.6 S / T A \theta$

$+\alpha 3.7 E P S \theta+\alpha 3.8$ PER $\theta+\alpha 3.9 P B V \theta+\alpha 3.10 \Theta$

4. $\mathrm{TD} / \mathrm{TA}=\alpha 4.0+\alpha 4.1 \mathrm{NPM} \theta+\alpha 4.2 R O A \Theta+\alpha 4.3 R O E \theta+\alpha 4.4 \mathrm{DR} \Theta+\alpha 4.5 \mathrm{DI} \Theta+\alpha 4.6$

$\mathrm{S} / \mathrm{TA} \Theta+\alpha 4.7 E P S \theta+\alpha 4.8$ PER $\theta+\alpha 4.9 P B V \Theta+\alpha 4.10 \Theta$

5. $\mathrm{DR}=\alpha 5.0+\alpha 5.1 \mathrm{NPM} \Theta+\alpha 5.2 \mathrm{ROA} \theta+\alpha 5.3 \mathrm{ROE} \theta+\alpha 5.4 \mathrm{TD} / \mathrm{TA} \Theta+\alpha 5.5 \mathrm{DI} \Theta+\alpha 5.6$

S/TA $\Theta+\alpha 5.7 E P S \theta+\alpha 5.8$ PER $\theta+\alpha 5.9 P B V \theta+\alpha 5.0 \Theta$

6. $\mathrm{DI}=\alpha 6.0+\alpha 6.1 \mathrm{NPM} \theta+\alpha 6.2 R O A \theta+\alpha 6.3 R O E \theta+\alpha 6.4 \mathrm{TD} / \mathrm{TA} \Theta+\alpha 6.5 \mathrm{DR} \Theta+\alpha 6.6$

S/TA $\Theta+\alpha 6.7$ EPS $\theta+\alpha 6.8$ PER $\theta+\alpha 6.9 P B V \theta+\alpha 6.10 \Theta$

7. $\mathrm{S} / \mathrm{TA}=\alpha 7.0+\alpha 7.1 \mathrm{NPM} \theta+\alpha 7.2$ ROA $\theta+\alpha 7.3 R O E \theta+\alpha 7.4 \mathrm{TD} / \mathrm{TA} \Theta+\alpha 7.5 \mathrm{DR} \Theta+\alpha 7.6$

DI $\Theta+\alpha 7.7 E P S \theta+\alpha 7.8$ PER $\theta+\alpha 7.9 P B V \theta+\alpha 7.10 \Theta$

8. $E P S=\alpha 8.0+\alpha 8.1 \mathrm{NPM} \Theta+\alpha 8.2$ ROA $\theta+\alpha 8.3 R O E \Theta+\alpha 8.4 \mathrm{TD} / \mathrm{TA} \Theta+\alpha 8.6 \mathrm{DR} \Theta+$

A8.6DI $\Theta+\alpha 8.7 \mathrm{~S} / \mathrm{TA} \Theta+\alpha 8.8$ PER $\Theta+\alpha 8.9 P B V \Theta+\alpha 8.10 \Theta$

9. $P E R=\alpha 9.0+\alpha 9.1 \mathrm{NPM} \theta+\alpha 9.2 R O A \Theta+\alpha 9.3 R O E \Theta+\alpha 9.4 \mathrm{TD} / \mathrm{TA} \Theta+\alpha 9.5 \mathrm{DR} \Theta+$ A9.6DI $\Theta+\alpha 9.7 \mathrm{~S} / \mathrm{TA} \Theta+\alpha 9.8$ EPS $\Theta+\alpha 9.9 P B V \Theta+\alpha 9.10 \Theta$

10. $P B V=\alpha 10.0+\alpha 10.1 \mathrm{NPM} \theta+\alpha 10.2 R O A \theta+\alpha 10.3 R O E \theta+\alpha 10.4 \mathrm{TD} / \mathrm{TA} \Theta+\alpha 10.5 \mathrm{DR} \Theta$ $+\alpha 10.6 \mathrm{DI} \Theta+\alpha 10.7 \mathrm{~S} / \mathrm{TA} \Theta+\alpha 10.8$ EPS $\theta+\alpha 10.9$ PER $\theta+\alpha 10.10 \Theta$

The model is in accordance with Circular Causation models which are a dynamically explicative model in which each variable seen interacts with other variables in the research or named IIE process Choudury and Hasan (2006).Therefore in order that the model can be processed by using simultaneous then with lag in the equation, Choudury and Hasan (2006). To prove that the hypothesis is true or not, must test the truth of the hypothesis that is $\mathrm{F}$ statistic and t test statistic or significance resulting from the test.By first determining the level of significance between $90 \%$ to $95 \%$ or error rate between $5 \%$ to $10 \%$, and pay attention to the number of observations (n). Based on the above then compare the t-table and t-arithmetic obtained from the processing with SPSS. Or see from the probability that results from data processing with the program. In this research the proposed hypothesis has one tail test (one-way test) and two tail test (two-way test). 
Where the proposed hypothesis is as follows:

Hypothesis:

Ha: independent variables together have a significant effect on the dependent variable.

H0: independent variables together have no significant effect on the dependent variable.

Variable hypothesis:

In relation to the use of the TSR methodology, where all variables simultaneously affect each other. Then the following hypothesis formulation is presented each variable:

a. Ha: After privatization and screening Shariah financial performance Net Profit Margin BUMN JII member is influenced significantly by Return on Asset (ROA).

H0: After privatization and screening Shariah financial performance Net Profit Margin BUMN JII members are not significantly influenced by Return on Assets (ROA).

b. Ha: After privatization and screening Shariah financial performance Net Profit Margin BUMN JII member is influenced significantly by Return on Equity (ROE)

H0: After privatization and screening Shariah financial performance Net Profit Margin BUMN JII member is not influenced significantly by Return on Equity (ROE).

c. Ha: after privatization and screening Shariah financial performance Net Profit Margin BUMN JII member is significantly influenced by Total Debt to Total Equity.

H0: After privatization and screening Shariah financial performance Net Profit Margin BUMN JII member is not significantly influenced by Total Debt to Total Equity).

d. Ha: after privatization and screening Shariah financial performance Net Profit Margin BUMN JII member is significantly influenced by Days Receivable.

H0: After privatization and screening Shariah financial performance Net Profit Margin BUMN JII member is not significantly influenced by Days Receivable.

e. Ha: After privatization and screening Shariah financial performance Net Profit Margin BUMN JII member is significantly influenced by Days Inventory.

H0: After privatization and screening Shariah financial performance Net Profit Margin BUMN JII member is not significantly influenced by Days Inventory.

f. Ha: After privatization and screening Shariah financial performance Net Profit Margin BUMN JII member is significantly influenced by Total Asset Turn over.

H0: After privatization and screening Shariah financial performance Net Profit Margin BUMN JII member is not significantly influenced by Total Asset Turn over.

g. Ha: after privatization and screening Shariah financial performance Net Profit Margin BUMN JII member is significantly influenced by Earning Per Shares.

H0: After privatization and screening Shariah financial performance Net Profit Margin BUMN JII member is not significantly influenced by Earning Per Shares.

h. Ha: After the privatization and screening of Sharia financial performance Net Profit Margin BUMN JII member is influenced significantly by Price Earnings Ratio.

H0: after privatization and screening Shariah financial performance Net Profit Margin BUMN JII member is not significantly influenced by Price Earnings Ratio.

i. Ha: after the privatization and screening of Shariah financial performance Net Profit Margin BUMN JII member is influenced significantly by Price to Book Value.

H0: After privatization and screening Shariah financial performance Net Profit Margin BUMN JII member is not significantly influenced by Price to Book Value. 
Furthermore, hypotheses are conducted in the same order of independent variables, where the dependent variable is the ROA, ROE, DER, DR, DI, S / TA, EPS, PER and PBV variables.

\section{Results and Research Analysis}

After processed using SPSS application, all variables are tested for normality and its heteroscedasticity. The purpose of normality testing is to estimate whether variable data if they are regressed will produce accurate estimation constant value or not. In general, the variable data to being used, 5 (five) variables declared free from heteroscedasticity those are NPM, ROA, ROE, EPS, PBV. While 5 variable is not or less free from heteroscedasticity those areDER, DR, DI, S / TA. PER.

From the table attached the result of processing using SPSS application, where data processing is calculating the correlation value of each variable for all SOEs used in this study.

Strong weak relationship of two variables is shown by the value of Pearson Correlation (R) where the values are generally divided into the following:

$0-0.25$ : the correlation is very weak

0.25 - 0.50: moderate correlation

0.50 - 0.75: strong correlation

0.75 - 1.00: very strong correlation

Correlation Relationships between Variables can be explained as follows:

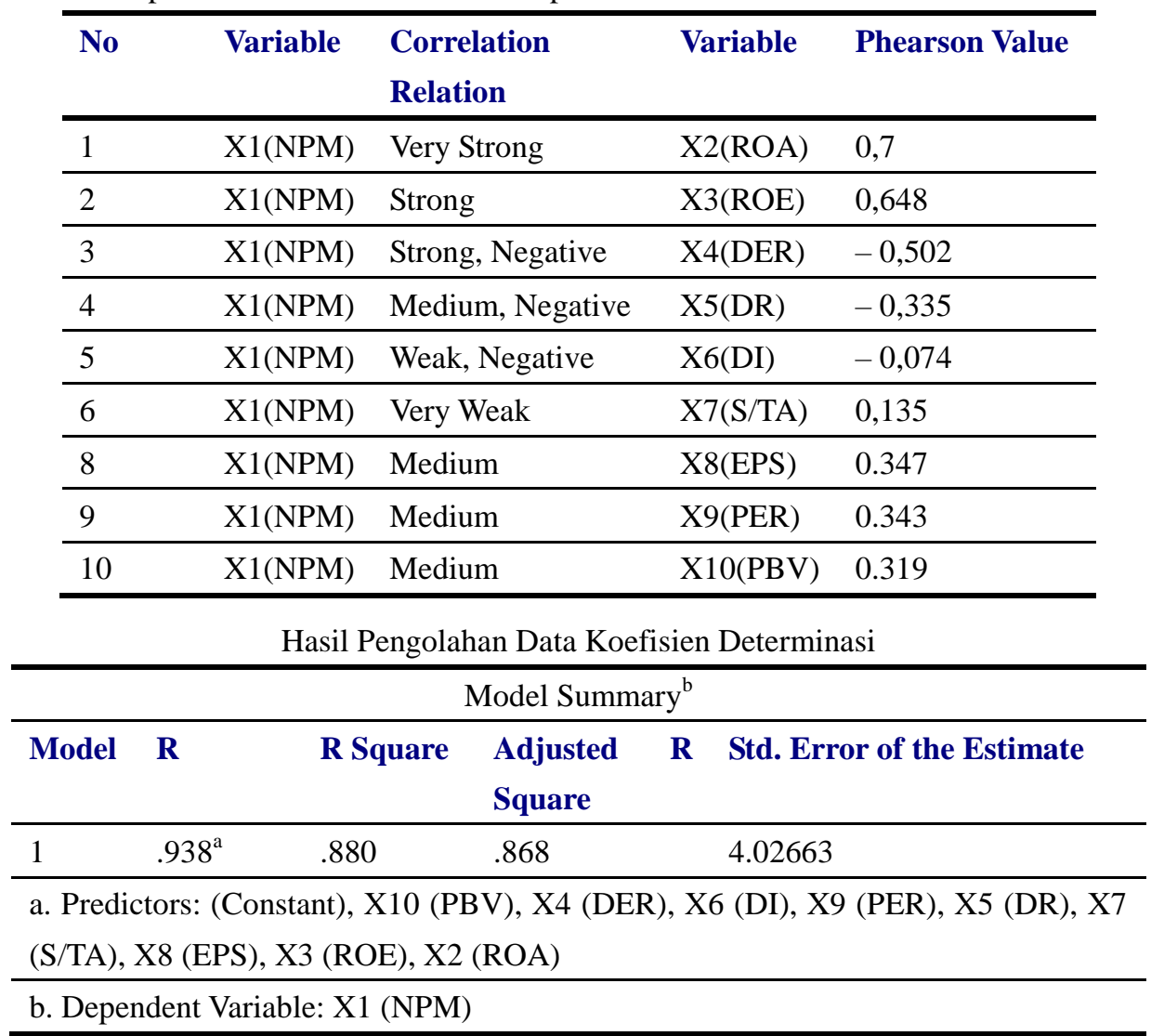

\section{Coefficient of Determination:}

The value of $\mathrm{R}$ square $=0.880$ from the table above shows that $88.0 \%$ of the variance $\mathrm{X} 1$ can be explained by the change in the variable X2 -X10. While the remaining $12.0 \%$ is explained by other factors outside the model.

It can be concluded that the dependent variable X1 (net profit margin) has $88 \%$ variance which can be explained by ROA, ROE, DER, S / TA, Days Receivable, Days Inventory, EPS, PER, PBV variables. 
www.cribflo.com/journal/index.php/ijibfr

International Journal of Islamic Banking and Finance Research

Vol. 2, No. 1; 2018

Results of Data Processing TEST F.

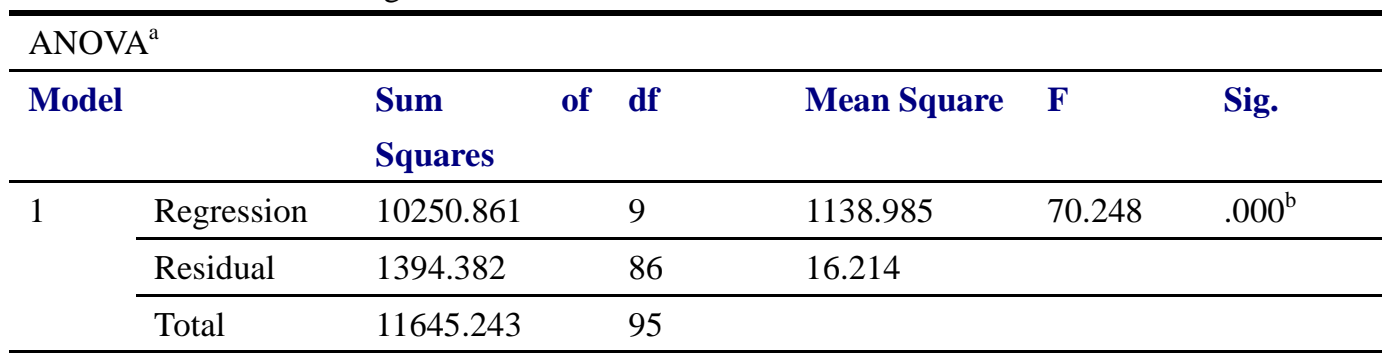

a. Dependent Variable: X1 (NPM)

b. Predictors: (Constant), X10 (PBV), X4 (DER), X6 (DI), X9 (PER), X5 (DR), X7 (S/TA), X8

(EPS), X3 (ROE), X2 (ROA)

Anova table above is a summary of Test F. Where $\mathrm{F}$ test is intended to test whether independent variables (X2,

$\mathrm{X} 3, \mathrm{X}, 8, \mathrm{X} 9, \mathrm{X} 10)$ all together significantly influence the variable dependent (X1).

Hypothesis:

Ha: independent variables together have a significant effect on the dependent variable.

H0: independent variables together have no significant effect on the dependent variable.

Basic Decision Making is as follows:

- If the probability ( $\mathrm{sig}$ value) $>0.05$ or $\mathrm{F}$ arithmetic $<\mathrm{F}$ table then $\mathrm{H} 0$ is not rejected

- If the probability (sig value) $<0.05$ or $\mathrm{F}$ arithmetic $>\mathrm{F}$ table then $\mathrm{H} 0$ is rejected

Decision:

In the above table of the results of regression processing obtained sig value $=0.000<0.05$, so $\mathrm{H} 0$ rejected, which means independent variables together significantly influence the dependent variable (X1).

Results of Data Processing TEST T

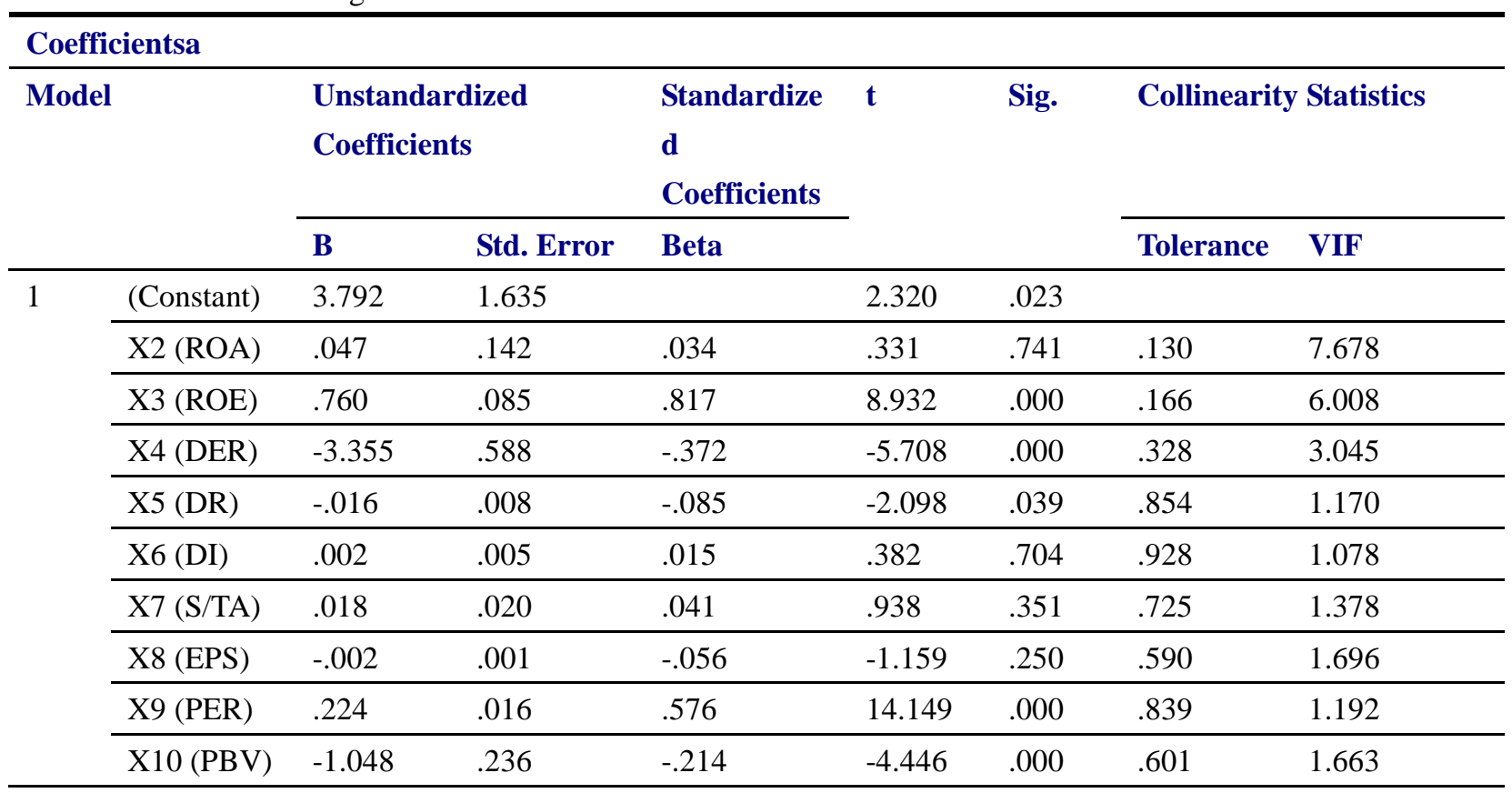

a. Dependent Variable: X1 (NPM)

The t test is intended to test whether the independent variable is partially significant to the dependent variable.

Table $\mathrm{T}$ test against other variables is presented in the attachment. 
Hypothesis testing

Hypothesis:

Ha: after privatization and syariah screening of independent variables partially significant effect on the dependent variable

H0: after privatization and syariah screening of independent variables (X2, X3, X4, X5, X7, X7, X8, X9, X10) partially no significant effect on the dependent variable

In accordance with the above explanation, the basic decision-making is as follows:

- If the probability (sig value) $>0.05$ or $-\mathrm{t}$ table $<\mathrm{t}$ count $<\mathrm{t}$ table then $\mathrm{H} 0$ is not rejected

- If the probability (sig value) $<0.05$ or $\mathrm{t}$ arithmetic $<-\mathrm{t}$ table or $\mathrm{t}$ arithmetic $>\mathrm{t}$ table then $\mathrm{H} 0$

rejected, received Ha.

Decision:

1. In the above table the sig value of the variable $\mathrm{X} 2=0.741>0.05$ so that $\mathrm{H} 0$ is not rejected, which means the independent variable X2 partially has no significant effect on the variable X1 (NPM).

2. In the table above the sig value. the variable $\mathrm{X} 3(\mathrm{ROE})=0.000<0.05$ so that $\mathrm{H} 0$ is rejected, which means that this independent variable partially positively and significantly influences the variable $\mathrm{X} 1$, the higher the variable value X3 (ROE), the higher the variable value X1 (NPM) apply vice versa.

3. In the table above the sig value of the variable $\mathrm{X} 4$ (DER) $=0.000<0.05$ so that $\mathrm{H} 0$ is rejected, which means that this independent variable is partially negatively and significant to the variable X1 (NPM). The higher the X4 (DER), the lower the X1. Vice versa. This is still in line with the explanation on the correlation between variables, where high debt will reduce profits, and otherwise low debt will increase profits.

4. In the table above the sig value of the variable X5 (DR) $=0.039<0.05$ so that $\mathrm{H} 0$ is rejected, which means that this independent variable is partially negatively and significant to the variable X1 (NPM). The higher the value of variable X5 (days receivable), the lower the value of variable X1, and vice versa. The explanation is that if the average day of receivables increases, the lower the profit.

5. In the table above the sig value. variable $\mathrm{X} 6(\mathrm{DI})=0.704>0.05$ so that $\mathrm{H} 0$ is not rejected, which means that this independent variable partially has no significant effect on variable $\mathrm{X} 1$.

6. In the table above the sig value of the variable $\mathrm{X} 7$ ( $\mathrm{S} / \mathrm{TA})=0.351>0.05$ so that $\mathrm{H} 0$ is not rejected, which means that this independent variable is partially no significant effect on the variable $\mathrm{X} 1$.

7. In the table above the sig value of the variable $\mathrm{X} 8$ (EPS) $=0.250>0.05$ so that $\mathrm{H} 0$ is not rejected, which means that this independent variable is partially no significant effect on the variable $\mathrm{X} 1$.

8. In the table above the sig value of the variable $\mathrm{X} 9$ (PER) $=0.000<0.05$ so that $\mathrm{H} 0$ is rejected, which means that this independent variable partially positively and significantly to the variable $\mathrm{X} 1$, the higher the X10 (PER), the higher the value of X1 (NPM), and vice versa.

9. In the table above the sig value of the variable $\mathrm{X} 10(\mathrm{PBV})=0.000<0.05$ so that $\mathrm{H} 0$ is rejected, which means that this independent variable is partially negatively and significantly affect the variable $\mathrm{X} 1$. The higher the X10, the lower the X1. Vice versa.

Thus we can compile the estimation equation of variable X1 (NPM) as follows:

$\mathrm{X} 1=3.792+0.047 * \mathrm{X} 2(\mathrm{ROA}) \Theta+0.76 * \mathrm{X} 3(\mathrm{ROE}) \Theta-3.355 * \mathrm{X} 4$ (DER) $\Theta-0.016 * \mathrm{X} 5$ (DR) $\Theta+0.002 * \mathrm{X} 6$ (DI) $\Theta$ $+0.018 * \mathrm{X} 7(\mathrm{~S} / \mathrm{TA}) \Theta-0.002 * \mathrm{X} 8$ (EPS) $\Theta+0.224 * \mathrm{X} 9$ (PER) $\Theta-1.048 * \mathrm{X} 10(\mathrm{PBV}) \Theta$.

Similarly, the simulation equation, other variables that are used as the dependent variable, in the same way and the same method obtained the estimation equation of each variable as follows: 


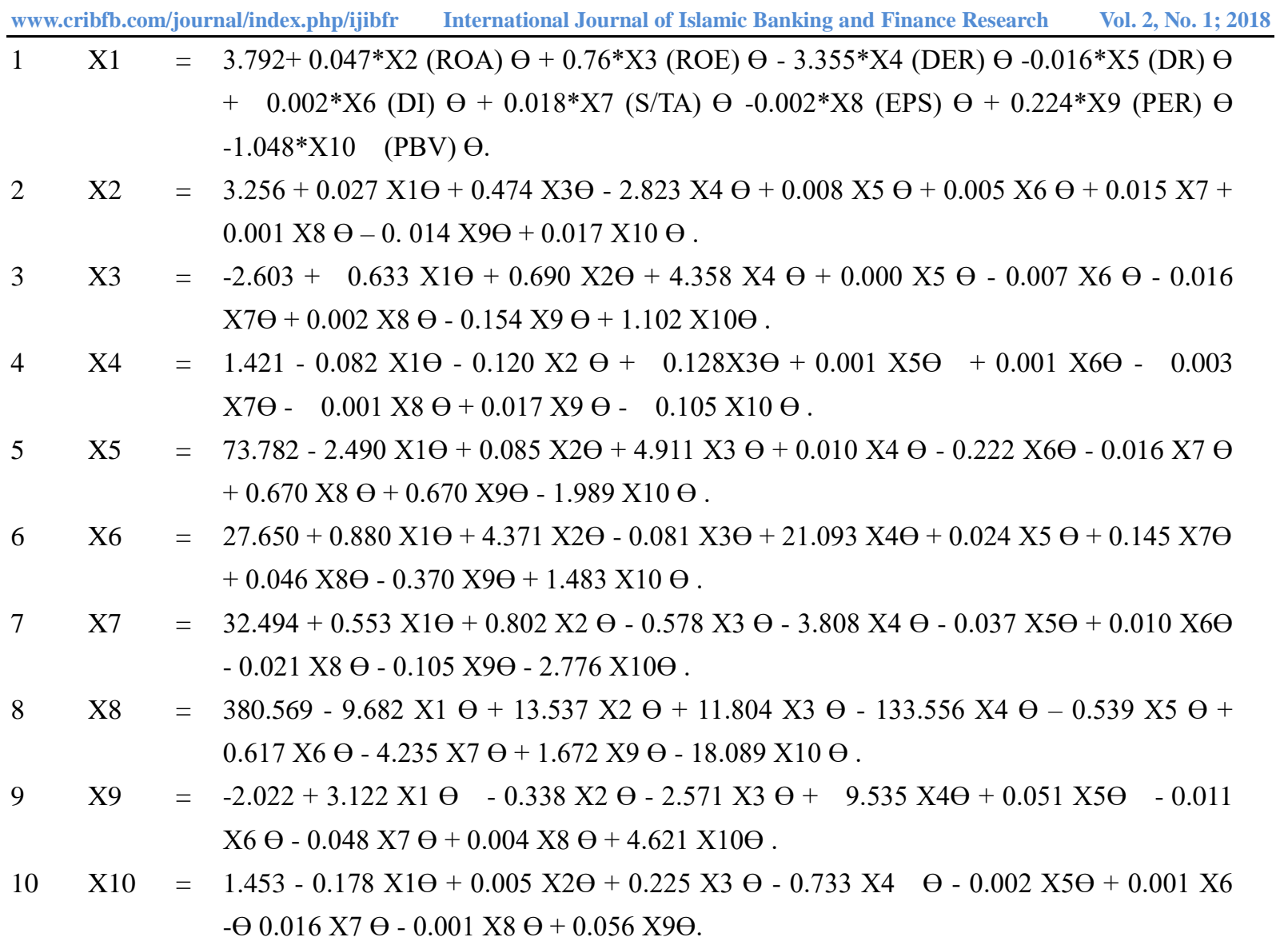

In general, hypothesis $1 \mathrm{a}$, after the privatization and screening of syariah variable NPM influenced significantly by the variable ROE, DER, DR, PER, PBV. While the variable NPM, ROA, DI, S / TA, EPS is not significantly affected.

Where each variable has embedded theta element $(\Theta)$, ie each variable is the result of the integration and evolution (IIE) interaction process. For example Net profit margin can be predicted from one variable return on asset, which has embbeded theta element. Theta ROA element is the return value is the result of the financial statements recorded by the employee of the financial department, where the records are performed after the proof of the sale fund or the bill has been entered in the form of transfer reports, sales reports. Once inputted, then the record will be checked by the supervisor. Reports will be periodic reports to management. If there is any improper adjustment will be made to be more accurate. It is a shuratic element, leading to a refinement of the return report in the end. Similarly, the results of the report can be a consideration for the Management whether action needs to be adjusted to report return obtained for example under the target or exceed the target. This process is continuously carried out such as circular causation, to bring about improvement in everything. Similarly, the variables ROE, DER, DR, DI, S / TA, EPS, PER and PBV. All of them have been embedded with theta element.

Anailisis Trend Explanation of trend of net profit margin variable at PT Aneka Tambang (Persero), it can be explained that NPM component is not free of influence, it can be seen that commodity price factor and economic growth also cause NPM change. That is why NPM variables need to be analyzed by simultaneous equations. In addition the theta factor has also been embedded on the NPM variable, since the profitability ratio is the result of the division of the net profit component with income. Where the components of net profit and income is the result of employee performance over a certain period. The work done is of course implemented with a mutually agreed system, this is a shuratic process in TSR theory. In the process of income-generating activities, there has 
also been a system of supervisory supervision and system. This is in order to lead to improvements to gain maslahat or benefits. So it goes on with other variables that have also been embedded with theta.

\section{Conclusion, Implication and Limitation of Research and Recommendations}

\section{Conclusion}

So from the analysis and discussion obtained the following conclusions:

- The variable data used in this study generally has normal residual distribution, so that it meets the requirements for regression.

- After tested visual heteroskedastistas each variable, seen as many as 5 variables, namely NPM, ROA, ROE, EPS and PBV has a random distribution, so if done regression, can produce accurate estimates. While the other 5 variables DER, DR, DI, S / TA, PER are seen to contain heteroscedasticity. Which, if used for regression, would be less accurate.

The conclusion of $\mathrm{T}$ test on partial variable is as follows:

$\checkmark$ Variable net profit margin (NPM) in each BUMN JII member, influenced significantly by ROE, DER, DR, PER, PBV. While other variables ROA, DI, S / TA, EPS have no significant effect. Significant influence both individually (partially) and collectively. This means ROE, DER (leverage), DR (day receivable), PER and PBV SOEs after privatization and screening sharia affects net profit margin significantly.

$\checkmark$ Variable return on asset (ROA) on every state owned member JII, influenced by ROE and variable, DER significantly. While the variables of NPM, DR, DI, S / TA EPS, PER and PBV either individually (partially) or together do not affect ROA.

$\checkmark \quad$ The return on equity (ROE) variables in each BUMN JII member are significantly influenced by NPM, ROA, DER, PER and PBV variables either individually or partially. Meanwhile, DR, DI, S / TA, EPS variables do not affect ROE.

$\checkmark \quad$ Debt to Equity Ratio (DER) variables in each BUMN JII member, influenced by significant variable of NPM, ROA, ROE, DER, PER and PBV. Variables DR, DI and EPS do not affect DER.

$\checkmark$ Days Receivable (DR) variables on each BUMN JII member, only influenced by NPM variable significantly. In addition, the variables, ROE, ROA, DI, DER, S / TA EPS, PER and PBV either individually (partially) or together do not affect the DR. This means that the average days of accounts receivable SOEs after privatization and in the sharia screening significantly influenced only Net Profit Margin.

$\checkmark$ Days Inventory Variable (DI) in every state-owned JII member, not influenced by one variable. All other variables, namely NPM, ROE, ROA, DR, DER, S / TA EPS, PER and PBV either individually (partially) or together do not affect DI variables or age of inventory of company goods.

$\checkmark$ Variable Asset Turn Over (S / TA) on every state owned member JII, influenced by one variable only that is EPS. While the other variables are NPM, ROE, ROA, DER, DR, DI, S / TA, PER and PBV either individually (partial) or together does not affect the variable S / TA. This means that Asset Turn Over can only be influenced by Earning Per Share, ie if S / TA increases, then EPS will increase and likewise.

$\checkmark \quad$ Variable Earning per Share (EPS) on each SOE member JII, significantly influenced all variables DER and S / TA. Other variables such as NPM, ROE, ROA, DR, DI, PER and PBV either individually (partially) or together do not affect EPS variables.

$\checkmark$ Variable Price Earning Ratio (PER) in each SOE member JII, significantly influenced by NPM, ROE, DER, and PBV. While the other variables are ROA, DR, DI, S / TA and EPS either individually (partially) or together does not affect the PER variable. This means that the performance of shares per 
share of SOEs after the privatization and in the screening is strongly influenced by operating profit, the condition of corporate debt and book value book value.

$\checkmark$ Variable Price to Book Value (PBV) in each BUMN member JII, significantly influenced by variable NPM, ROE, DER and PER. While the variables of ROA, DR, DI, S / TA EPS, either individually (partially) or together do not affect PBV. This means that the performance of book value per share of SOE after privatization and in sharia screening is influenced by operating profit, debt and stock price.

Conclusions regarding trend variables after privatization and screening of Sharia during the study period have different trends as follows:

In the NPM trend table it can be concluded that, the increase is the NPM of ANTM PGAS, PTBA, SMGR, WSKT shares. While stable NPM is PTPP and WIKA shares, which decreases is TLKM stock.

In the ROA trend table can be concluded that the increase is ROA shares PGAS, PTBA, SMGR, TLKM, WIKA. While stable ROA is PTPP and WSKT, which decreases is ANTM stock.

In the table of trend ROE can be concluded that the increase is ROE shares PGAS, PTBA, SMGR, TLKM. While the ROE is down is ANTM. PTPP, WIKA, WSKT,

In the DER trend table can be concluded that the decline is DER shares PGAS, PTBA, SMGR, TLKM, PTPP, WIKA, WSKT. The rising DER is ANTM stock. This may indicate that after privatization and screening, the debts of SOEs almost all have a downward trend.

In the DR trend table it can be concluded that the decreasing or improving is DR stock of ANTM, PGAS, PTBA, PTPP, SMGR, TLKM, while DR which rise or worsen is DR WIKA and WSKT.

In the DI trend table it can be concluded that the decreasing or improving is IN stock of ANTM, PGAS, PTBA, PTPP, SMGR, TLKM, WIKA. While the DI is rising or deteriorating is IN WSKT stock.

On the S / TA trend table can be concluded that the decline or worsen is S / TA stock ANTM, PTPP, SMGR, WIKA, WSKT. While the S / TA is rising or improving does not exist. While the stable is $\mathrm{S} / \mathrm{TA}$ shares PGAS, PTBA, TLKM.

In the EPS trend table it can be concluded that an increase or improvement is the EPS of PGAS stock. PTBA, PTPP.SMGR, WIKA, WSKT. While the EPS is down or worsen is the stock of ANTM and TLKM.

In the trend table PER can be concluded that the increase or improve is PER stock of ANTM, PGAS. PTBA, PTPP.TLKM SMGR, WSKT. While the PER is down or worsen is the stock of WIKA.

On the PBV trend table can be concluded that the increase or improve is PBV stock ANTM, PTBA, PTPP. TLKM, WSKT. While the PBV is down or worsen is shares PGAS, SMGR, WIKA, WSKT.

Theoretical and Managerial Implications

In general, research on the financial performance and stock performance of eight (8) Sharia SOEs JII members over a 17-year period can be explained that basically all financial ratio variables in theory are generally only independent, can also be a dependent variable and big or small always affect each other. Although not all variables but it can be concluded that the aspects of sharia and privatization can give a real effect on the company's performance both in financial and stock value. That for one dependent variable not all independent variables can give a significant influence. For example, although theoretically can be explained the close relationship between the average variables of receivable (DR) and operating income (NPM), that with the better the average day of receivable (decrease) then the business profit should increase. But ROA and ROE are equally related to profitability does not significantly affect the average variable day receivable or DR. This indicates that there are still other unexplained factors from this study.

While managerial implications, it can be conveyed that to support more and more explanations obtained in the study, the parties related to the development of stock exchanges and SOEs in order to encourage more 
state-owned enterprises in the privatization and can be classified into the appropriate sharia companies. So that investors are increasingly interested to instill the excess funds in the form of halal shares, and can be a reference material for further research. So this requires a simpler privatization process, where the privatization process is currently regulated by many government regulations and laws. On the one hand these laws and regulations are very good in order to avoid unfairness in the implementation of privatization. But on the other hand can hamper the acceleration of the privatization process.

\section{Limitations of Research and Advice}

Limitations of this research is located in research methodology where the method used in this dissertation data processing is by using approach of Tawhidi String Relation (TSR) where TSR method has the main principle of interaction integration and evolution and the existence of function by using model of circular causation that is model where the exogenous variable has the opportunity to become the endogenous variable in the model, therefore in this research the simultaneous equation model is used.Because this equation model is already eligible to be used as an analytical tool. In addition, research using the TSR methodology model has not been widely published, either in the form of a journal or dissertation that specifically discusses this research.

The data used in this study is secondary data. This is a drawback in this study, since secondary data are not entirely representative of the purpose of this study. So in the future, it is expected that the research can use primary data in the form of real survey results by interviewing directly to the management of each BUMN related to Sharia aspect and privatization.

From the conclusions presented above in general can be understood that the factor of financial performance is determined by the company's profit and debt structure. The significance of a variable simply illustrates the strength of the influence of the independent variable in each change of the dependent variable, but not adequately explained by only 10 variables and a period of 17 years. It is also related to the uniform timing of observations on issuers within JII, due to the discrepancy of IPO time and the limited number of financial ratio variables. Furthermore it is suggested to expand the number of variables studied with a longer period of time.

\section{References}

Ang. Robert. (1997). Buku Pintar Pasar Modal. Jakarta: Salemba Empat.

An-Nabhani, Taqiyuddin (1966), Membangun Sistem Ekonomi Alternatif Perspektif Islam, Surabaya.

Badan Kebijakan Fiskal, (2015). Kebijakan Fiskal untuk Mendukung Pertumbuhan Ekonomi yang Tinggi dan Berkelanjutan dengan Tetap Menjaga Stabilitas Perekonomian. Artikel 30/KLI/2015, Departemen $\begin{array}{llll}\text { Keuangan } & \text { RI. Jakarta diunggah }\end{array}$ https://www.kemenkeu.go.id/SP/kebijakan-fiskal-untuk-mendukung-pertumbuhan-ekonomi-yang-ting gi-dan-berkelanjutan-dengan-tetap.

Banaluddin, I. (2007). The Performanse of Privatized SOEs In Malaysia. School Of Management Universiti Sains Malaysia.

Bappenas (2009), Penyebab dan Dampak Krisis Keuangan Global, Buku Pegangan Penyelenggaraan Pemerintahan dan Pebangunan Daerah, Jakarta.

Brigham, Eugene F. (1995), Fundamentals of Financial Management, Seventh Edition, Orlando: The Dryden Press New York.

Brigham dan Houston. (2010). Dasar-dasar Manajemen Keuangan Buku 1. (Edisi 11). Jakarta: Salemba Empat.

BPS, (2011). Perkembangan beberapa indicator utama social-ekonomi Indonesia. Jakarta: Katalog BPS:3101015., Agustus 2011.

BPS, (2006). Perkembangan Index Industri Besar Dan Sedang 2002-2006. CV.Gading 
Komunikatama, Jakarta 2006.

Bungin, Burhan H.M, (2007). Penelitian Kualitatif : Komunikasi, Ekonomi, Kebijakan Publik, dan Ilmu social, Jakarta : Kencana Prenama Media Group

Chang, H.J., Palma, G., and Whittaker, D.H. (1998). The Asian Crisis: Introduction, Cambridge Journal of Economics (Special Issues on the Asian Crisis), Vol. 22, No. 6, pp. 649-52.

Choudhury, M. A. (2013). Complexity and endogeneity in economic modeling. Kibernetes, Vol.42 no.2 pp.226-240, Emerald Group Publishing Limited.

Choudhury, M. A. (2011). Contributions to Economics Analysis: Islamic Economics and Finance. Emerald Group Publishing Limited, UK.

Choudhury, M. A. (1999). Comparative Economic Theory : Occidental and Islamic Perspective. Boston-Dordrecht-London : Kluwer Academic Publisher.

Choudhury, M. A. (1996). Markets as a system of social contracts. International Journal of Socila Economic, Vol.23, No.1 1996, pp.17-36

Choudhury, M. A. (2000). A social contractarian theory of Market. International Journal of Socila Economic, Vol.35, No.4 2008, pp.239-268.

Choudhury, M. A. (2008). Islam versus liberalism : contrasting epistimological enquiries. International Journal of Socila Economic, Vol.27, No.3 2008, pp.149-212.

Choudhury, M. A. (2009). Some structural issues in demand and supply of global food production. Journal of Economic Study, Vol.34, No.1 2009, pp.91-113.

Choudhury, M. A., Harahap, S. S. (2009). Complementing community, business and microenterprise by Islamic epistemology methodology: A case study of Indonesia. International Journal Islamic and Middle Eastern Finance and Management, Vol.2, No.2 2009, pp. 139-159.

Choudhury, M. A., Harahap, S. S. (2007). Degreasing corporate governance in an ethico-economic general equilibrium model of unity of knowledge. Corporate Governance Emerald Group Publishing United, Vo7, No.5 2007, pp. 599-611.

Choudhury, M. A., Hoque, M. Z. (2004). An Advance Exposition of Islamic Economics and Finance. United Kingdom SA 48 8LT: The Edwin Mellen Press, Ltd.

Cooper, Donald R, Pamela S. Schindler. (2003). Business Research Methods. Eighth Edition.

D’Souza, J. Megginson, W. Nash, R. (2001). Determinants of Performance Improvements in Privatized Firms:

The Role of Restructuring and Corporate Governance. AFA 2001 New Orleans.

Darmadji Tjipto dan Hendry M Fakhruddin, (2001). Pasar Modal di Indonesia, Salemba Empat, Jakarta.

Djojohadikusumo. Sumitro (1999). Artikel: Wawancara Prof. Sumitro Djojohadikusumo: Jika Lima Tahun Lalu Pak Harto Mundur...... Majalah Tempo NO. 04/XXVIII/30 Mar - 5 Apr 1999, Indonesia.

Domberger, Simon \& Piggott, John, (1986). Privatization Policies and Public Enterprise a Survey, The Economic Record, Vol 62, No. 177.

Elzadora, Rida, (2009). Pengaruh Variabel Makro dan Mikro Ekonomi terhadap Harga Saham Perusahaan, Universitas Sebelas Maret, Surakarta

Emmanuel S. Savas, (1996). Privatizing the Public Sector (Chatham, N.Y: Chatham House Publishers, 1982).

Fahmi, Irham. (2012). Analisis Laporan Keuangan. Cetakan Ke -2. Bandung: Alfabeta.

Faisal H. Basri, (2003), Privatisasi Versus Neo-Sosialisme Indonesia, pustaka LP3ES Indonesia

Fama.E.F. (1980). Agency Problem and the Theory of the Firm. Journal of Political Economy,88; 288-307.

Forsyth ,Peter et, al (2004), Preparing Asean For Open Sky, Final Report. Australia, Monash International Pty Ltd. 
Frydman, R., Gray, C., Hessel, M., Rapaczynski, A. (1997). Private Ownership And Corporate Performance: Some Lesson From Transition Economies. J E L Classification.

Chapman, Patricia. (1990). Guidelines on Preservation Policies in the Archives and. Libraries

Heritage. Paris: UNESCO.

Ghozali, I dan Castellan J, (2002). Statistik Non-Parametrik, Badan Penerbit Universitas Diponegoro.Indonesia.

Ghozali, Imam. (2007). Aplikasi Analisis Multivariate Dengan Program SPSS. BP-Universitas Diponogoro, Semarang

Gulo, W. (2002). Metode Penelitian. Jakarta: PT. Grasindo.

Gulo, W. (2005). Metodologi Penelitian . Jakarta: PT. Grasindo.

Hamda, Hanung Hisbullah SH, (2011). Transaksi Saham di Pasar Modal Menurut Perspektif Hukum Islam, Paper: di download dari http://hanunghisbullahhamda.blogspot.co.id/2011/04/transaksi-saham-di-pasar-modalmenurut.html

Hamid, Abdul, (2009). Pasar Modal Syariah, Lembaga Penelitian UIN, Jakarta.

Hamzah, Ardi. (2008). Analisa Karakteristik Perusahaan dan Ekonomi Makro pada Return Saham Syariah dan Non Syariah. Jurnal Studi Manajemen, Universitas Trunojoyo.

Hanani, Anisa Ika. (2011). Analisis Pengaruh Earning Per Share (EPS), Return on Equity (ROE), dan Debt to Equity Ratio (DER) Terhadap Return Saham Pada PerusahaanPerusahaan dalam Jakarta Islamic Index (JII) Periode Tahun 20052007. Universitas Diponogoro. Semarang.

Hanke, Steve, (1987), Privatization and Development, California: ICS.

Harahap, Mursal. (2001). Analisis Pengaruh Leverage Keuangan dan Risiko Saham terhadap Return Saham Perusahaan di Bursa Efek Indonesia. Tesis, Universitas Indonesia. Jakarta.

Harahap, S.S. (2010). Research Methodology: an Islamic Perspective. Trisakti Unicversity, IEF Post Graduate Program, 2010, Jakarta.

Higgins, Robert C. (2003). Analysis for Financial Management. New york: The McGraw-Hill.

Hijriah, Almas, (2007). Pengaruh Faktor Fundamental dan Risiko Sistematik Terhadap Harga Saham

Properti di Bursa Efek Jakarta, Tesis, Universitas Sumatera Utara, Medan:.

Hizamuddin Jamalluddin, (2012). Presentation of Understanding of Islamic Bank's Balance Sheet to Member of Iraq House of Representative, Bank Islam Malaysia,

Hulwati. (2001).Transaksi Saham di Pasar Modal Indonesia Perspektif Hukum Ekonomi Islam, Yogyakarta: UII Pres.

Husein, Umar. (2001). Manajemen Risiko Bisnis: Pendekatan Finansial dan Nonfinansial. Jakarta: PT. Gramedia Pustaka

Husnan. S. (2004). Dasar-Dasar Teori Portofolio dan Analisis Sekuritas Edisi Ketiga. Yogyakarta: UPP AMP YKPN.

Hutchinson (1991) ,Efficiency Gains Through Privatization of UK Industries. In A.F,Ott and K.Hartley, editors, Privatization and Economic Efficiency,87-107, Hants, U.K. Edward Elgar.

Ikatan Akuntan Indonesia. (2007). Standar Akuntansi Keuangan. Edisi 2007. Penerbit: Salemba Empat . Jakarta.

Ibnu Qudamah Almaqdisi, (1997). Al-Mughni, Juz IX. Riyadh: Darul Ilmi,tth

Jogiyanto, Hartono. (2003). Teori Portofolio dan Analisis Investasi. Edisi 3, Penerbit BPFE Fakultas Ekonomi Universitas Gadjah Mada, Yogyakarta.

Jumingan, (2006). Analisis Laporan Keuangan , Cetakan Pertama, PT Bumi Aksara, Jakarta. 
Kantor Menteri Negara Pendayagunaan BUMN. (1998). Master Plan Reformai BUMN. Jakarta.

Kasmir. (2010), (2012). Analisis Laporan Keuangan. Jakarta: Rajawali Press

Laporan Masterplan (2005). Revitalisasi BUMN 2004-2009, penerbit Kantor Menteri Negara

BUMN, publikasi terbatas

Lubis, Maria. (2004). Dampak Privatisasi terhadap Kinerja Keuangan Perusahaan. Tesis Ekonomi Universitas Gadjah

http://pascaeko.ugm.ac.id/wp/wp-content/text/gok-maria-lubis.pdf.Diakses 2 Maret 2010.

Megginson, William L., (2003) and (2004). Database of the worldwide's privatization, University of Oklahoma, unpublished.

Megginson, W., Nash, R., Netter, J., and Schwartz, A. (2000), The long run return to investor in share issue privatization, Financial Management, pp. 67-77.

Megginson, W. L, Robert C. Nash, and Matthias Van Randenborgh . (1994). The Financial and

Operating Performance of Newly Privatized Firms : An International Empirical Analysis”. The Journal of Finance. Vol XLIX No.2.

Megginson, W. L dan Netter Jeffry M, (2001), From State to Market : A Survey of Empirical Studies on Privatization, Jurnal of Economic Literature Vol XXXIX (June 2001) pp.321-389.

Megginson.W.L. (2000). Privatization (effect and management of sale of state owned enterprise). URL. http://www.findarticles.com. Spring,

Meyer, K. E., Moller, I. B. (1998). Managing deep restructuring: Danish experiences in Eastern

Germany. European Management Journal, 16, 4, 411-21.

Meyer, K. E. (2004). Stakeholder Influence and Radical Change : A Coordination Game Perspective. Asia Pacific Journal of Management. 21,235-253.

Mugiyati (2013), Privatisasi Aset Publik Sebagai Kebijakan Ekonomi Menurut Konsep Al Milkiyah. Jurnal Al Hikmah, Volume 3, Nomor 2, September 2013. Fakultas Syarieeah IAIN Sunan Ampel Surabaya.

Mulyadi. (2007). Sistem Perencanaan dan Pengendalian Manajemen. Salemba. Empat. Jakarta.

Munari, F. (2002). The effects of privatization on corporate R \& D units; evidence from Italy and

France. R \&D Management. 32.3.

Munawir. S, (2004). Analisis Laporan Keuangan, Edisi Ke-4, Liberty, Yogyakarta.

Munawir, S, (2002). Analisis Laporan Keuangan, Edisi Kedua, YPKN, Yogyakarta.

Musa, Ali Masykur. (2016). Artikel: BUMN sebagai Mesin Pertumbuhan Ekonomi, Koran Sindo diunggah dari https://nasional.sindonews.com/read/956914/168/bumn-sebagai-mesin-pertumbuhan-ekonomi.

Nabhani, Taqiyuddin. (2004), An-Nizham Al-Iqtishadi fi Al-Islam, Beirut: Darul Ummah,

Nawawi. H. Hadar (2003); Manajemen Sumber Daya Manusia Untuk Bisnis Yang Kompetitif, Cetakan ke-7, Gadjah Mada University Press, Yogyakarta.

Noormuhammad, (2016). Artikel: SEJARAH PEREKONOMIAN INDONESIA. Dipublikasi dihttps://id.linkedin.com/pulse/sejarah-perekonomian-indonesia-ahmad-noormuhammad.

Nugroho, Safri. (2003). Privatisasi BUMN, Kebijakan yang Menguntungkan Negara atau Investor? Analisa dari Privatisasi Beberapa BUMN di Indonesia. SINERGI Vol 5(2) 2003. hal.5-12. MM UII Yogyakarta.

Patriadi, Pandu, (2003). Studi Banding Kebijakan Privatisasi BUMN di Beberapa Negara, dalam Analisa Ekonomi dan Keuangan, Vol. 7. No. 4, Des. 2003, Departemen Keuangan RI, Jakarta. Peraturan Pemerintah Republik Indonesia Nomor 45 Tahun (1995). Tentang Penyelenggaraan Kegiatan Di Bidang Pasar Modal Presiden Republik Indonesia ( Lembaran Negara Republik 
Indonesia Tahun 1995 Nomor 86)

Porter, Michael E. (1985). Competitive Strategy. Creating and Sustaining Superior Performance, The Free Press, New York.

Porter, Michael E. (1990). The Competitive Advantage of Nation" New York The Free Press.

Prahalad K. Basu. (1994). Demystifying Privatization in Developing Countries. International Journal of Public Sector Management. Vol 7 No 3, pp 44-55.

Pranoto, T. (2011). Faktor-Faktor yang Mempengaruhi keberhasilan Privatisasi BUMN: Studi Komparatif Indonesia-Malaysia. Disertasi. Universitas Indonesia. Depok.

Rivai, Veithzal dan Sagala, Ella (2009). Manajemen Sumber Daya Manusia untuk Perusahaan. Edisi Kedua.Jakarta : Penerbit PT. Raja Grafindo Persada.

Qardhawi, Yusuf. DR.(1985). Awamil As-Sa'ah wa Al-Marunah fi As-Syari'ah Al-Islamiah. cet. 1. Mesir: Dar Al-Shahwah..

Qardhawi, Yusuf, DR. (1985). Al Halal wa al haram fil Islam”, Beirut : Dar Al Ma'rifah

Rahardjo, Budi . (2005). Laporan Keuangan Perusahaan . Yogyakarta: Gadjah Mada University

Press.

Rahardjo, Budi. (2009). Dasar-dasar Analisis Fundamental Saham Laporan Keuangan Perusahaan. Penerbit Gajah Mada University Press.

Ramadhan K.H, Sugiarta Sriwibawa dan Abrar Yusra, (1994). Dari Monopoli menuju Kompetisi” Grasindo, PT Gramedia Widiasarana Indonesia, Jakarta.

Rao, Ramesh K. S. (1995). Financial Management: Concepts and Application 3rd. Ohio: International Thomson Publishing

Ritonga, Jamiluddin, (2005). Riset Kehumasan, PT.Grasindo,

Riyanto, Bambang, (1997), Dasar - dasar Pembelanjaan Perusahaan, Edisi 4. BPFE, Yogyakarta

Robert K,Yin. (1989). Case Study Research Design And Method: Volume 5. London: Sage Publicatios, Inc.

Savas, E.S. (2000). Privatization And Public-Private Partnerships" Clatham House Publishers Seven Bridges Press. LLc New York London.

Sawir, Agnes. (2005). Analisis Kinerja Keuangan dan Perencanaan Keuangan Perusahaan. PT Gramedia Pustaka, Jakarta.

Schumpeter, J. A. (1934). The Theory of Economic Development, Harvard University Press, Boston, MA. 80.

Schumpeter, Joseph .A. (2002). The Economy As A Whole Seventh Chapter of The Theory of

Economic Development. Industry and Innovation, Vol 9. No.1/2,93-145, April/Agustus 2002.

Sekaran, Umar. (2000). Metodologi Penelitian. Penerbit Salemba Empat, Yogyakarta.

Sembel, Roy. (2001). Analisa Kinerja Keuangan dan Perencanaan keuangan perusahaan. Jakarta: PT Gramedia Pustaka Utama.

Setiawati, Sinta Arie. (2004). Analisis kinerja perusahaan sebelum dan sesudah Initial Public Offerings. Tesis Fakultas Ekonomi Magister Akuntansi Universitas Indonesia.

Siamat, Dahlan. (2004). Manajemen dan Lembaga Keuangan. Jakarta: Lembaga Penerbit Fakultas Ekonomi Universitas Indonesia.

Simamora, Henry. (2000). Basis Pengambilan Keputusan Bisnis. Salemba Empat. Jakarta.

Sinta Wardani dan Rachma Fitriati,(2010). Jurnal Ilmu Administrasi dan Organisasi, Mei-Agust (2010) hlm. 90-100 ISSN 0854-3844 Volume 17, Nomor 2.

Sjafri, Sairin. (2002). Perubahan Sosial Masyarakat Indonesia perspektif antropolgi. 
Yogyakarta: Pustaka Pelajar.

Solimun, Nurjanah dan Rinaldo, (2006. Pemodelan Persamaan Struktural Pendekatan PLS dan

SEM .

Fakultas Mipa dan Program Pasca Sarjana Unibraw Malang.

Sulistyastuti, Dyah Ratih. (2005). Saham dan Obligasi. Yogyakarta: Universitas Atmajaya,.

Sudarini. (2005). Penggunaan Rasio Keuangan dalam Memprediksi Laba Pada Masa yang Akan Datang (Studi Kasus di Perusahaan Perbankan yang Terdaftar di Bursa Efek

Jakarta), Jurnal Akuntansi \& Manajemen, Vol. XVI, No. 3, Desember, Hal. 195-207

Sukhemi. (2007). Evaluasi Kinerja Keuangan Pada PT. Telkom, Tbk, Vol.1.

Stiglitz, J . )1988). Economics of the Public Sector, New York: W.W. Northon.

Subalno, (2009). Analisis Pengaruh Faktor Fundamental dan Kondisi Ekonomi Terhadap Return Saham, Tesis, Universitas Dipenogoro, Semarang:

Sucipto. (2003). Penilaian Kinerja Keuangan. Jurnal Akuntansi. Universitas Sumatera Utara.

Medan.

Sugiharto, (2007), Peran Strategis BUMN, PT Gramedia Jakarta.

Sumodiningrat, G. (2002). Ekonometrika Pengantar. BPFE-Yogyakarta: Yogyakarta.

Syahatah, Husein \& Fayyadh, Athiyah, (2004). Bursa Efek: Tuntunan Islam dalam Transaksi di Pasar Modal (Adh-Dhawâbit asy-Syar‘iyah li at-Ta‘âmul fî Sûq al-Awraq al-Mâliyah), Penerjemah A. Syakur. Surabaya: Pustaka Progressif,

Syahyunan, (2004). Manajemen Keuangan I (Perencanaan, Analisis dan Pengendalian Keuangan), USU Press, Medan.

Tandelilin, Eduardus. (2001). Analisis Investasi dan Manajemen Portofolio. BPFEUGM: Kanisius Yogyakarta.

The World Bank , (2001). Group -Documents \& Reports. The Determinants of Enterprise

Restructuring in transition : an assessment evidence.

Tunggal, Amin Widjaja. (2000). Dasar-Dasar Analisis Laporan Keuangan. Jakarta: Rineka Cipta.

Van Horne, James C. Dan M.Jhon Wachowicz, (2005). Prinsip-Prinsip Manajemen keuangan, Diterjemahkan oleh Aria Farahmita, Amanugrani, dan Taufik Hendrawan, edisis kedua belas, PT.Salemba Empat, Buku Satu, Jakarta.

Villalonga, B. (2000). Privatization and Efficiency: Differentiating Ownership Effects from

Political, Organizational, and Dynamic Effects. Journal of Economic Behavior and

Organization, 42: 43-74.

Wahbah Al Zuhaily, (1989). Al fiqh al Isalmy Wa Adillatuh, Cetakan III Daar al fik.

Warren, Fees, Reeve,( 2005). Pengantar Akuntansi, Edisi 21, Penerbit Salemba

Empat, Jakarta.

Wiranta, Sukarna (2011), Privatisasi BUMN dan Perannya Terhadap Pembangunan Ekonomi Nasional. Jurnal Ekonomi dan Kebijakan Publik. LIPI Jakarta.

Wiryawan, N, J., dan Wiryawan, Z. Z. (2003). Program Privatisasi Di Indonesia Dilihat Dari Pengalaman Privatisasi Di Beberapa Negara lain. Jurnal Usahawan No.03 Th XXXII Maret 2003.

World Bank (2000), Special Report: Social Monitoring and Early Response Unit (SMERU). www,smeru.or.id

Yarrow, G. (1986). Privatization in theory and practic. Economic Policy, 2: 324-377.

Yumna A, Kusumawardhani N, Suharyadi A (2017). Memahami Ketimpangan di Indonesia. Buletin Info Resiko F edisi 1_2017. DJPPR Kementerian Keuangan Republik Indonesia.

Website: 
Indonesia Capital Market Directory. 2005. Jakarta Stock Exchange.

http://www.wikipedia.com

http://www.emeraldinsight.com

http://www.bi.go.id/web/id/Moneter/Operasi+Moneter/Suku+Bunga+SBI/

http://www.bursamalaysia.com/website/bm/products and services/islamic capital

market/ ICM Islamic

Investment.htm

http://www.finance.yahoo.com

http://www.idx.co.id/Home/ProductAndServices/ShariaMarket/tabid/155/language/id-

ID/ Default.aspx

http://portal.bumn.go.id/

Krisis Ekonomi Kapitalis: Siklus yerulang

https://sofianok08.wordpress.com/2015/09/08/krisis-ekonomi-kapitalis-siklus-yang-berulang/

http://ekonomi.kompas.com/read/2015/01/23/173056326/BPK.Ungkap.Penyebab.Utama.Kerugian.BUMN.Sela ma.Ini

https://www.cnnindonesia.com/ekonomi/20150120165442-78-26006/penyertaan-modal-negara-ke-bumn-menda pat-penolakan-dpr/

Appendix

\begin{tabular}{|c|c|c|c|c|c|c|c|c|c|c|c|}
\hline \multicolumn{12}{|c|}{ Correlations } \\
\hline & & X1 & $\mathrm{X} 2$ & X3 & $\mathrm{X} 4$ & X5 & X6 & X7 & X8 & X9 & X10 \\
\hline & & (NP & (RO) & (RO) & (DE & (DR) & (DI) & $(\mathbf{S} / \mathbf{T}$ & (EPS & (PER & (PBV \\
\hline & & M) & A) & E) & R) & & & A) & ) & ) & ) \\
\hline \multirow{5}{*}{$\begin{array}{l}\text { X1 } \\
\text { (NPM } \\
\text { ) }\end{array}$} & Pearson & 1 & $.700^{*}$ & $.648^{* * *}$ & $-.502^{*}$ & -.335 & -.074 & .135 & $.347^{*}$ & $.343^{*}$ & $.319^{* *}$ \\
\hline & Correlation & & * & & & & & & & & \\
\hline & Sig. & & .000 & .000 & .000 & .001 & .473 & .188 & .000 & .000 & .001 \\
\hline & (2-tailed) & & & & & & & & & & \\
\hline & $\mathrm{N}$ & 103 & 103 & 103 & 103 & 96 & 96 & 96 & 103 & 103 & 103 \\
\hline \multirow{5}{*}{$\begin{array}{l}\mathrm{X} 2 \\
\text { (ROA } \\
\text { ) }\end{array}$} & Pearson & $.700^{* * *}$ & 1 & $.809^{* * *}$ & $-.567^{*}$ & -.262 & .019 & .082 & $.543^{*}$ & -.205 & $.411^{\text {** }}$ \\
\hline & Correlation & & & & * & $* *$ & & & $*$ & & \\
\hline & Sig. & .000 & & .000 & .000 & .010 & .853 & .425 & .000 & .037 & .000 \\
\hline & (2-tailed) & & & & & & & & & & \\
\hline & $\mathrm{N}$ & 103 & 103 & 103 & 103 & 96 & 96 & 96 & 103 & 103 & 103 \\
\hline \multirow{5}{*}{$\begin{array}{l}\text { X3 } \\
\text { (ROE } \\
\text { ) }\end{array}$} & Pearson & $.648^{* * *}$ & $.809^{*}$ & 1 & -.140 & -.240 & -.078 & -.110 & $.412^{*}$ & -.228 & $.537^{* *}$ \\
\hline & Correlation & & * & & & * & & & $*$ & * & \\
\hline & Sig. & .000 & .000 & & .158 & .019 & .450 & .287 & .000 & .021 & .000 \\
\hline & (2-tailed) & & & & & & & & & & \\
\hline & $\mathrm{N}$ & 103 & 103 & 103 & 103 & 96 & 96 & 96 & 103 & 103 & 103 \\
\hline \multirow{3}{*}{$\begin{array}{l}\mathrm{X} 4 \\
\text { (DER } \\
\text { ) }\end{array}$} & Pearson & $-.502^{*}$ & -.567 & -.140 & 1 & $.270^{*}$ & -.013 & -.289 & -.432 & .003 & -.060 \\
\hline & Correlation & $*$ & ** & & & $*$ & & ** & ** & & \\
\hline & $\begin{array}{l}\text { Sig. } \\
\text { (2-tailed) }\end{array}$ & .000 & .000 & .158 & & .008 & .903 & .004 & .000 & .979 & .546 \\
\hline
\end{tabular}


WwW.cribfb.com/journal/index.php/ijibfr International Journal of Islamic Banking and Finance Research Vol. 2, No. 1; 2018

\begin{tabular}{|c|c|c|c|c|c|c|c|c|c|c|c|}
\hline & $\mathrm{N}$ & 103 & 103 & 103 & 103 & 96 & 96 & 96 & 103 & 103 & 103 \\
\hline \multirow{4}{*}{$\begin{array}{l}\mathrm{X} 5 \\
(\mathrm{DR})\end{array}$} & Pearson & $-.335^{*}$ & -.262 & $-.240^{*}$ & $.270^{* * *}$ & 1 & .030 & -.143 & -.202 & .060 & -.065 \\
\hline & Correlation & & ** & & & & & & & & \\
\hline & $\begin{array}{l}\text { Sig. } \\
\text { (2-tailed) }\end{array}$ & .001 & .010 & .019 & .008 & & .775 & .164 & .049 & .558 & .529 \\
\hline & $\mathrm{N}$ & 96 & 96 & 96 & 96 & 96 & 96 & 96 & 96 & 96 & 96 \\
\hline \multirow{4}{*}{$\begin{array}{l}\text { X6 } \\
\text { (DI) }\end{array}$} & Pearson & -.074 & .019 & -.078 & -.013 & .030 & 1 & .021 & .128 & -.060 & -.061 \\
\hline & Correlation & & & & & & & & & & \\
\hline & $\begin{array}{l}\text { Sig. } \\
\text { (2-tailed) }\end{array}$ & .473 & .853 & .450 & .903 & .775 & & .839 & .215 & .560 & .558 \\
\hline & $\mathrm{N}$ & 96 & 96 & 96 & 96 & 96 & 96 & 96 & 96 & 96 & 96 \\
\hline \multirow{4}{*}{$\begin{array}{l}\text { X7 } \\
\text { (S/TA } \\
\text { ) }\end{array}$} & Pearson & .135 & .082 & -.110 & $-.289^{*}$ & -.143 & .021 & 1 & -.158 & -.019 & $-.296^{*}$ \\
\hline & Correlation & & & & & & & & & & \\
\hline & $\begin{array}{l}\text { Sig. } \\
\text { (2-tailed) }\end{array}$ & .188 & .425 & .287 & .004 & .164 & .839 & & .123 & .853 & .003 \\
\hline & $\mathrm{N}$ & 96 & 96 & 96 & 96 & 96 & 96 & 96 & 96 & 96 & 96 \\
\hline \multirow{4}{*}{$\begin{array}{l}\text { X8 } \\
\text { (EPS) }\end{array}$} & Pearson & $.347^{* *}$ & $.543^{*}$ & $.412^{* *}$ & $-.432^{*}$ & -.202 & .128 & -.158 & 1 & -.140 & $.225^{*}$ \\
\hline & Correlation & & & & & & & & & & \\
\hline & $\begin{array}{l}\text { Sig. } \\
\text { (2-tailed) }\end{array}$ & .000 & .000 & .000 & .000 & .049 & .215 & .123 & & .158 & .023 \\
\hline & $\mathrm{N}$ & 103 & 103 & 103 & 103 & 96 & 96 & 96 & 103 & 103 & 103 \\
\hline \multirow{4}{*}{$\begin{array}{l}\text { X9 } \\
\text { (PER) }\end{array}$} & Pearson & $.343^{\text {** }}$ & -.205 & $-.228^{*}$ & .003 & .060 & -.060 & -.019 & -.140 & 1 & .134 \\
\hline & Correlation & & * & & & & & & & & \\
\hline & $\begin{array}{l}\text { Sig. } \\
\text { (2-tailed) }\end{array}$ & .000 & .037 & .021 & .979 & .558 & .560 & .853 & .158 & & 176 \\
\hline & $\mathrm{N}$ & 103 & 103 & 103 & 103 & 96 & 96 & 96 & 103 & 103 & 103 \\
\hline \multirow{4}{*}{$\begin{array}{l}\text { X10 } \\
\text { (PBV) }\end{array}$} & Pearson & $.319^{\text {** }}$ & $.411^{* * *}$ & $.537^{* *}$ & -.060 & -.065 & -.061 & -.296 & $.225^{*}$ & .134 & 1 \\
\hline & Correlation & & & & & & & ${ }^{* *}$ & & & \\
\hline & $\begin{array}{l}\text { Sig. } \\
\text { (2-tailed) }\end{array}$ & .001 & .000 & .000 & .546 & .529 & .558 & .003 & .023 & .176 & \\
\hline & $\mathrm{N}$ & 103 & 103 & 103 & 103 & 96 & 96 & 96 & 103 & 103 & 103 \\
\hline
\end{tabular}

Rangkuman Uji Normalitas dan Heteroskedasitas Data Variable

\begin{tabular}{|l|l|l|l|}
\hline Variabel & Grafik Normalitas & $\begin{array}{l}\text { Scatter Diagram } \\
\text { Heteroskedasticiy }\end{array}$ & $\begin{array}{l}\text { Normal/ Heteroskedastisitas } \\
\text { atau tidak }\end{array}$ \\
\hline NPM & $\begin{array}{l}\text { Data Variabel Normal dan } \\
\text { Tidak Heteroskedastisitas }\end{array}$ & \\
\hline
\end{tabular}




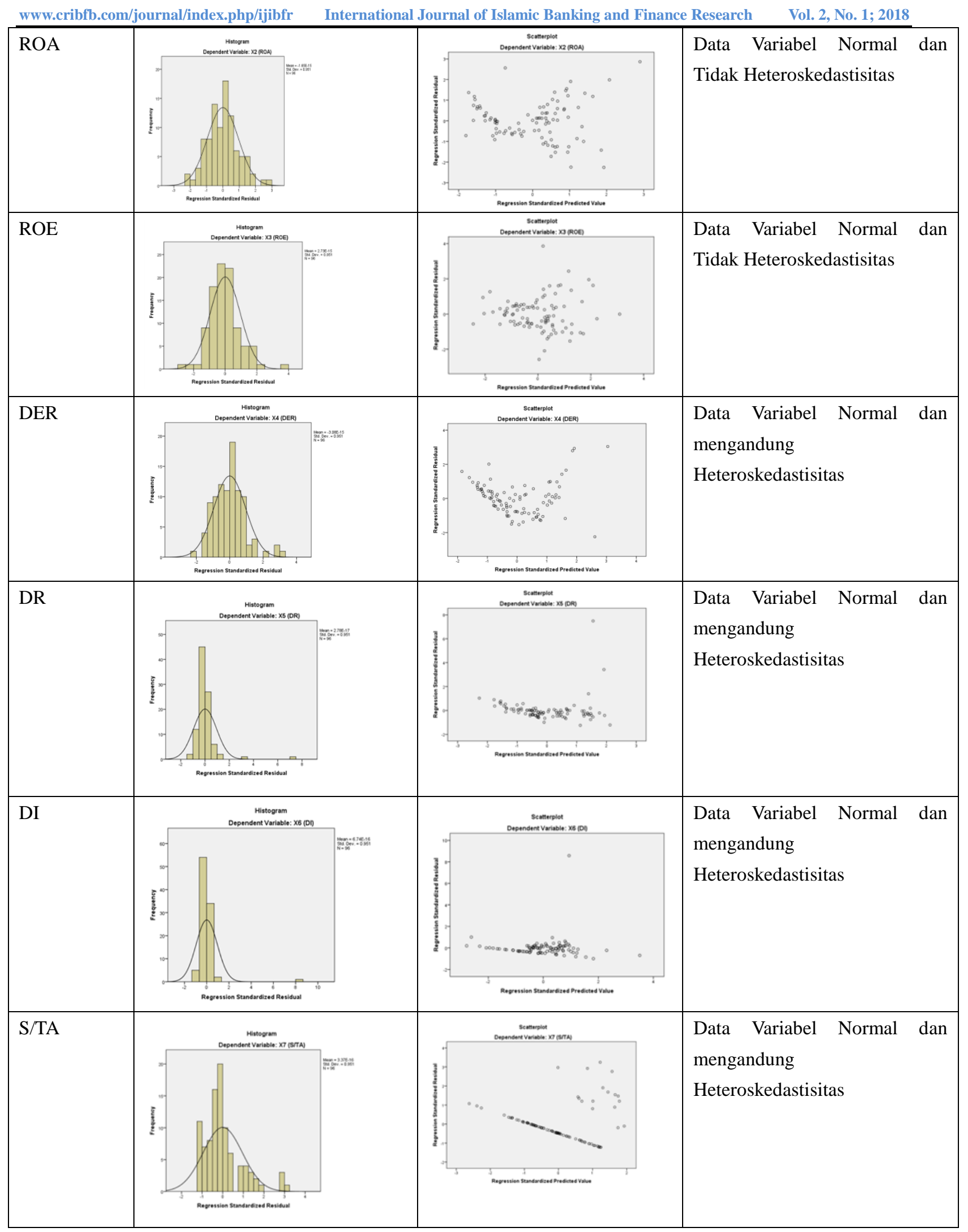




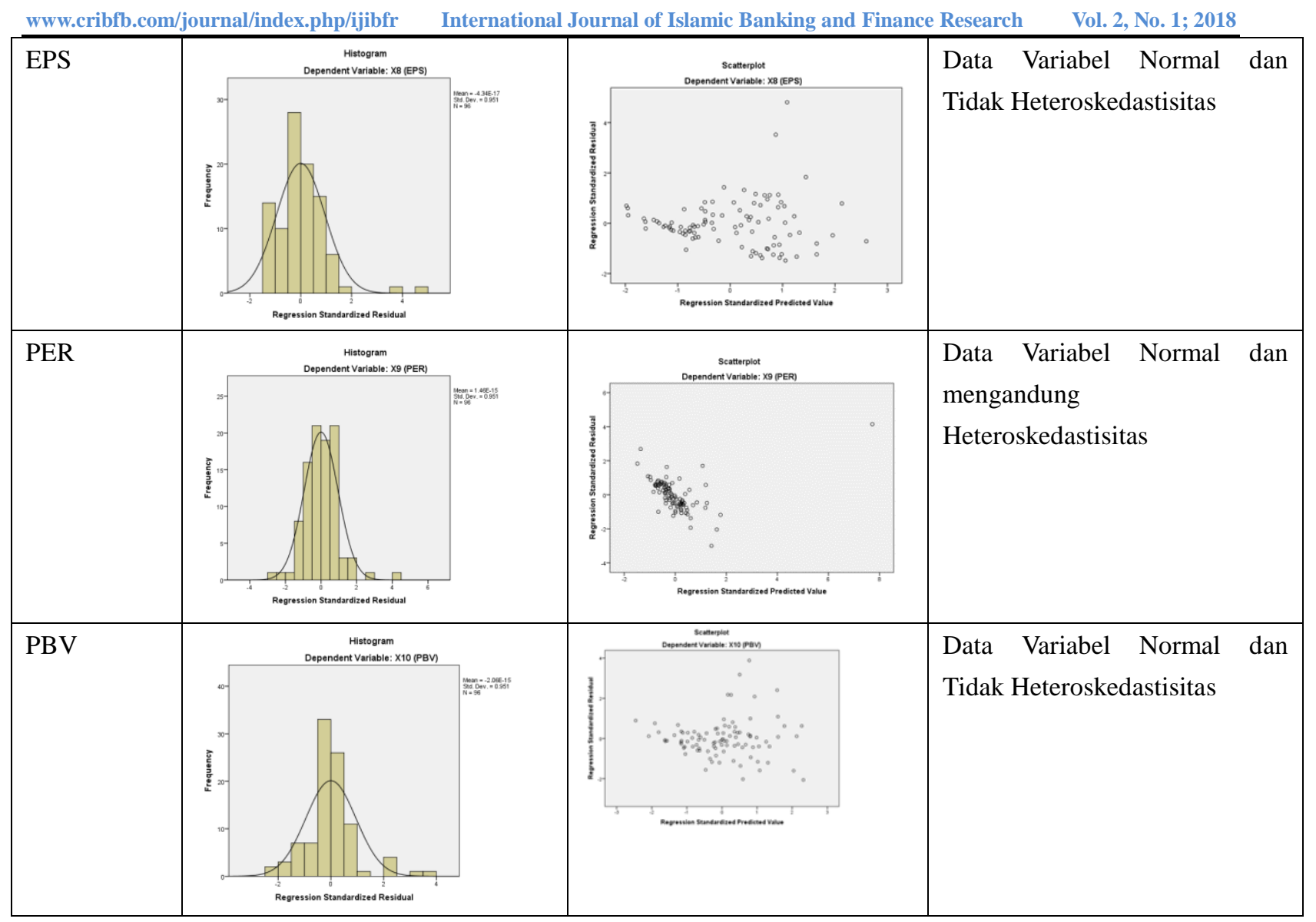

\section{Copyrights}

Copyright for this article is retained by the author(s), with first publication rights granted to the journal.

This is an open-access article distributed under the terms and conditions of the Creative Commons Attribution license (http://creativecommons.org/licenses/by/4.0/). 